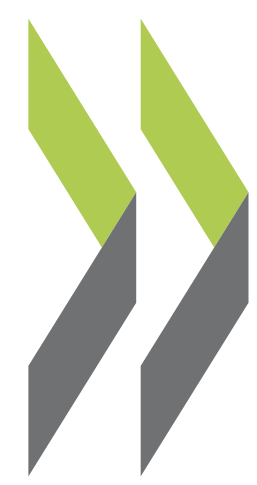

OECD Science, Technology and Industry Working Papers $2021 / 08$

Targeting R\&D intensity in Finnish innovation policy

\section{Matthias Deschryvere,}

Kai Husso,

Arho Suominen 
OECD Working Papers should not be reported as representing the official views of the OECD or of its member countries. The opinions expressed and arguments employed are those of the authors. Working Papers describe preliminary results or research in progress by the author(s) and are published to stimulate discussion on a broad range of issues on which the OECD works. Comments on Working Papers are welcomed, and may be sent to Directorate for Science, Technology and Innovation, OECD, 2 rue AndréPascal, 75775 Paris Cedex 16, France.

\section{Note to Delegations:}

This document is also available on ONE M\&P under the reference code:

DSTI/STP/TIP(2021)1/FINAL

This document, as well as any data and any map included herein, are without prejudice to the status of or sovereignty over any territory, to the delimitation of international frontiers and boundaries and to the name of any territory, city or area.

The statistical data for Israel are supplied by and under the responsibility of the relevant Israeli authorities. The use of such data by the OECD is without prejudice to the status of the Golan Heights, East Jerusalem and Israeli settlements in the West Bank under the terms of international law.

(C) OECD 2021

The use of this work, whether digital or print, is governed by the Terms and Conditions to be found at http://www.oecd.org/termsandconditions. 


\title{
Targeting R\&D intensity in Finnish innovation policy
}

\author{
Matthias Deschryvere*, Kai Husso** and Arho Suominen* \\ *VTT Technical Research Centre of Finland \\ ** Ministry of Economic Affairs and Employment of Finland
}

\begin{abstract}
Finland has been setting research and development (R\&D) intensity targets for almost 50 years. This paper explores the Finnish national policy experience in fostering public and private investments in R\&D. Three key insights are the following: a) a systemic and integrated policy approach needs an impactful co-ordination and governance mechanism; b) a balanced innovation system with well-working joint public-private partnership efforts and mechanisms will do better in absorbing shocks; c) a key strategy to absorb shocks to the economy and society is to invest in long-term capabilities. This study also provides an overview of the factors influencing the level of R\&D intensity. The current $4 \%$ target to be reached by 2030 was set in 2019 but thus far relatively few policy actions have been introduced to operationalise it. With these dynamics and uncertainty, it remains to be seen if the target will be reached by 2030 .
\end{abstract}

Keywords: research and development (R\&D), R\&D intensity targets, R\&D policy, innovation policy, Finland

JEL codes: L52, O30, O38

Acknowledgements: This policy paper was initiated as a case study project (contract VN/12374/2019) financed by the Ministry of Economic Affairs and Employment of Finland. We thank OECD TIP delegates and experts Agni Spilioti, Vasileios Gongolidis, Antonios Gypakis and the TIP secretariat team Caroline Paunov, Sandra Planes-Satorra, Hunter McGuire and OECD reviewers Alessandra Colecchia, Dirk Pilat and Hélia Costa for their valuable comments. We would also like to express our gratitude to all the stakeholders that participated in the survey and the interviews for this study. 


\section{Table of contents}

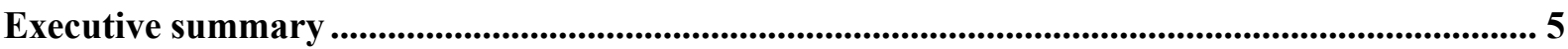

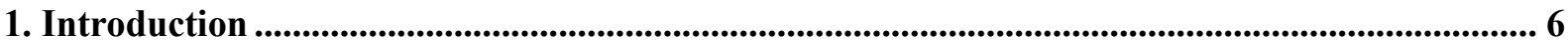

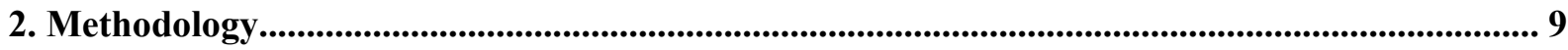

3. The Finnish experience with R\&D target setting ..................................................................... 10

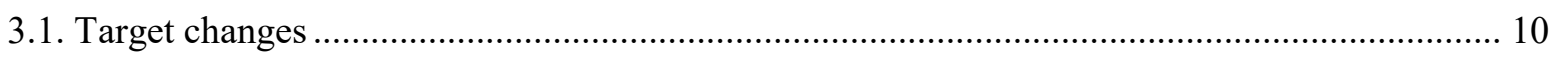

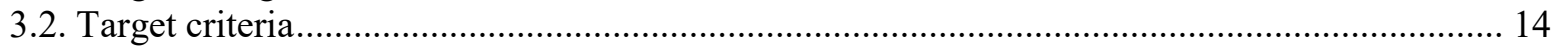

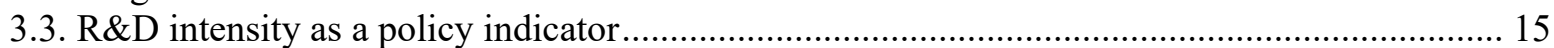

3.4. Specific indicator challenges to measure business-led innovation ................................................ 16

4. The Finnish experience implementing R\&D targets and policies ..................................................... 17

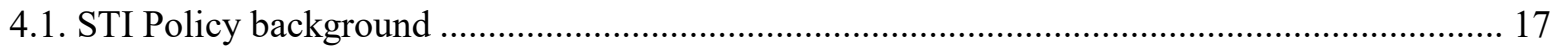

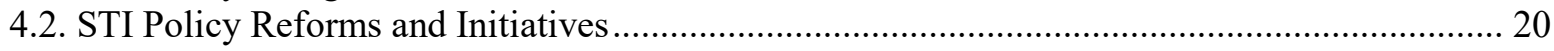

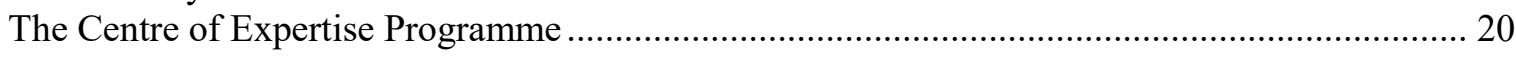

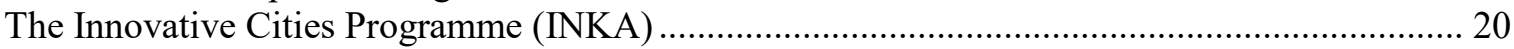

The Strategic Centres for Science, Technology and Innovation (SHOKs) ……............................. 20

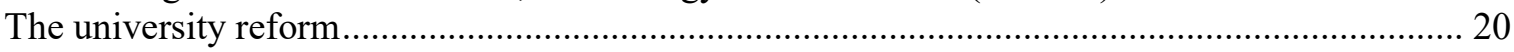

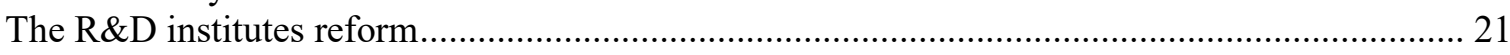

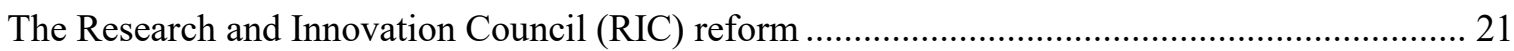

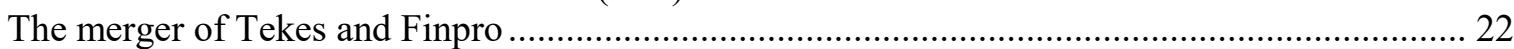

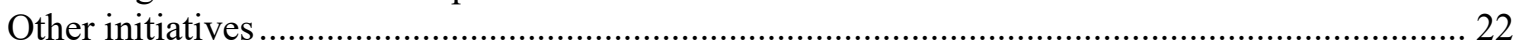

4.3. Successful policies: changes in governance and turns in policy-making ................................ 23

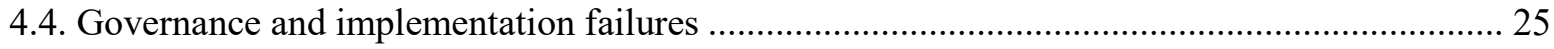

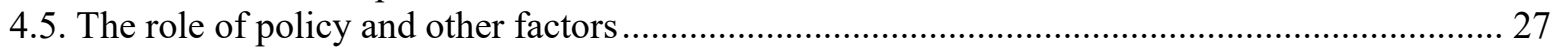

5. Conclusions and policy lessons ............................................................................................................ 31

Annex A. The evolution of Finland's R\&D expenditures by selected sector ...................................... 34

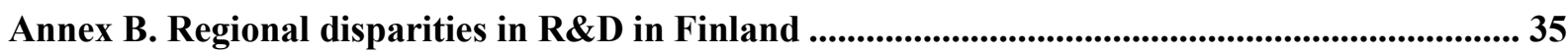

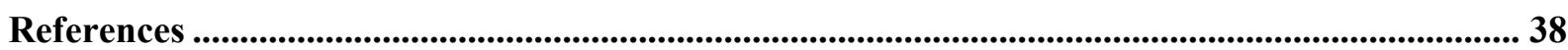




\section{Executive summary}

Finland has almost 50 years of valuable experience with research and development (R\&D) intensity ${ }^{1}$ target setting. The first target of $1.7 \%$ for 1980 was set in 1973 and since then it gradually climbed up to reach the current $4 \%$ target set in 2005 . Finland's performance on reaching these targets varies over time and can essentially be divided into two periods. Throughout the period between 1973 - when R\&D intensity targets were first introduced - and 2004, the level of R\&D intensity increased continuously and all targets except one were met.

However, the 4\% R\&D intensity targets set over 2005-2019, the period of focus in this study, have never been reached. After a peak at 3.73\% in the recession year 2009, R\&D intensity started to decline until it reached $2.72 \%$ in 2016 . Since then no major change has occurred. With these dynamics and uncertainty, it remains to be seen if the current $4 \%$ target will be reached by 2030, and if so under which expected economic growth scenario. The most recent $4 \%$ target was set in 2019 but thus far relatively few policy actions have been introduced to operationalise it.

Official $4 \%$ targets have proved challenging to meet because of the realities of the political, economic and social operating environments since the early 2010s. Elements that hindered the favourable evolution of R\&D performance were driven by science, technology and innovation (STI) policy factors like the weakening of collaborative culture and policy advice mechanisms, but increasingly also by contextual factors, such as the state of the economy. By the end of the 2000s, the leading Finnish industrial sectors of information and communication technologies (ICT) and forestry started to lose their position in global markets and value chains. The trade balance weakened rapidly and government foreign debt almost doubled in the period 2008-2015 from €54bn to €100bn. The economy stagnated throughout the entire period starting from the financial crisis in 2008 until 2017, when the GDP in real terms was for the first time higher than in 2008. For these reasons, among other factors, the preconditions for reaching the R\&D intensity target of $4 \%$ faded away, and STI policy gradually lost its position as a priority.

Based on this long-term experience with R\&D target-setting, the study distilled the following three key lessons that are of relevance to Finland's peers as well as to Finland's current and future policymakers when setting R\&D intensity in a sustainable and impactful manner. (1) A systemic and integrated policy approach, which preferably should be supported by national long-term vision and strategy, needs an impactful coordination and governance mechanism or forum. The ability of any such body to have impact depends on its authority and its mandate given by political actors. (2) A balanced innovation system with well-functioning Public-Private Partnership (PPP) efforts and mechanisms will do better in strengthening the economy and absorbing shocks. Balance should be present in terms of paying attention to all key stakeholders in the innovation system, and including consistent political buy-in and support needed for multilateral trust-building and increasing both private and public R\&D investments. (3) A strategy able to absorb shocks must invest in long-term capabilities. Capability building should happen based on a diversity of skills and focus on more intense cooperation between various stakeholders.

\footnotetext{
${ }^{1} \mathrm{R} \& \mathrm{D}$ intensity at the country level is defined as the volume of $\mathrm{R} \& \mathrm{D}$ expenditures as a percentage of GDP (Gross Domestic Product).
} 


\section{6 | TARGETING R\&D INTENSITY IN FINNISH INNOVATION POLICY}

\section{Introduction}

The main goal of this study is to explore the Finnish national policy experience in fostering public and private investments in R\&D. This is achieved by investigating the practices in R\&D target setting in Finland over time; the implementation challenges that arose and how they have been addressed; the role of policy versus the role of other contextual factors; the successes and failures in the implementation of R\&D targets; and the lessons learned over the years about the use of R\&D intensity targets.

The study is part of a series of 11 country case studies developed in the context of the OECD project on R\&D intensity (2019-20), conducted by the Working Party on Innovation and Technology Policy (TIP). The 11 case studies were developed by Australia, Finland, France, Germany, Greece, Hungary, Ireland, Korea, the Netherlands, Poland and the European Union. The R\&D intensity levels and policy experiences differ significantly across those countries (Figure 1), making cross-country analysis particularly insightful (OECD 2021).

\section{Finland's $R \& D$ performance in the OECD context}

In 2019, Finland's gross domestic expenditure in R\&D accounted for $2.79 \%$ of GDP, which is above the OECD average (2.47\%) and the average for the EU-27 area (2.10\%) (Figure 1). Businesses expenditures in R\&D (BERD) accounted for $1.83 \%$ of GDP (i.e. $66 \%$ of total $R \& D$ expenditures).

Figure 1. Total R\&D expenditures (of which business expenditures) in selected economies, 2019 or latest year available

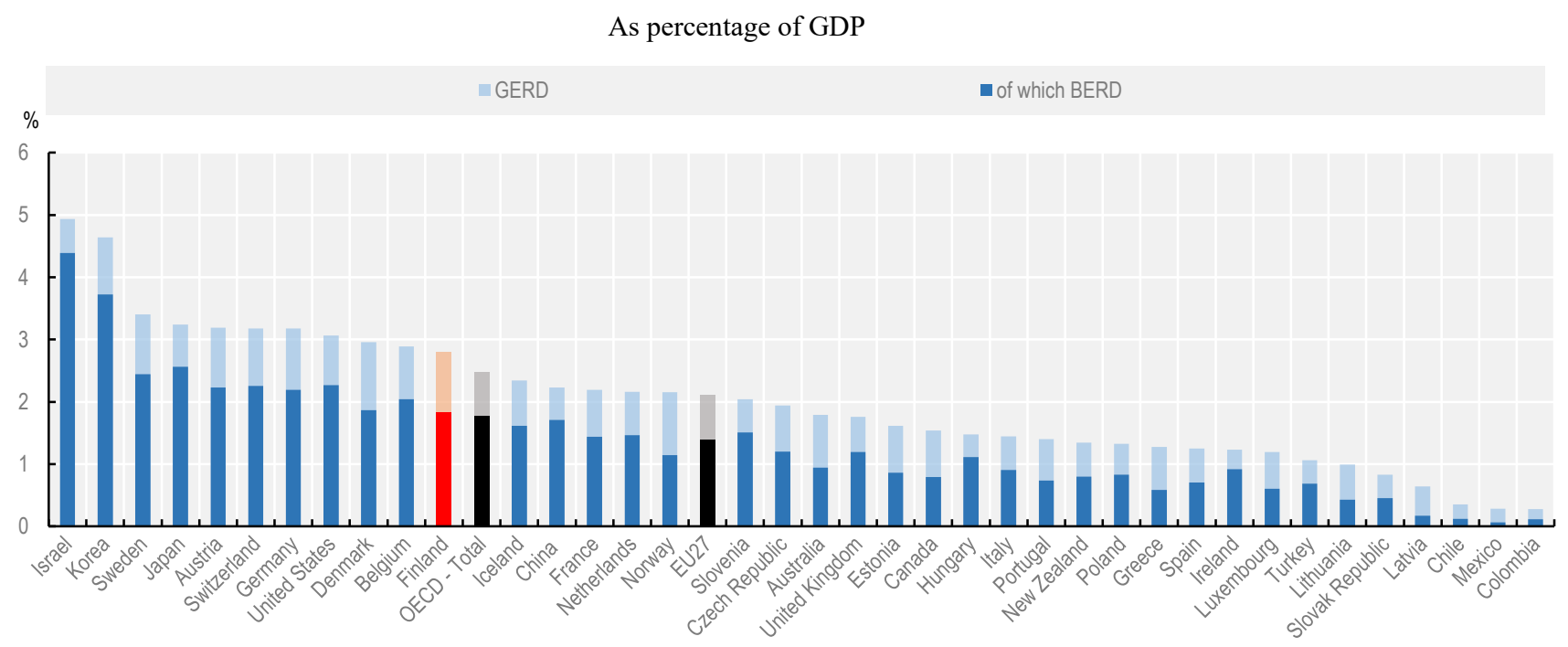

Note: The graph illustrates the Gross domestic expenditure on R\&D (GERD) and the Business expenditure on R\&D (BERD) as a percentage of GDP.

Source: OECD (2021), "Main Science and Technology Indicators", OECD Science, Technology and R\&D Statistics (database), https://doi.org/10.1787/data-00182-en (accessed on 01 April 2021). 
Finland's R\&D intensity grew steadily between 1981 (1.15\% of GDP) and the 2008-09 financial crisis. After reaching a peak in 2009 (3.73\% of GDP), R\&D intensity levels have been declining (Figure 2). Businesses expenditures in R\&D (BERD) have been the main driver of Gross domestic expenditure on R\&D (GERD) over time. The ICT equipment $(27.7 \%)$, the information and communication services (17\%) and the electrical equipment and machinery (16.4\%) sectors account for the lion's share of business R\&D expenditures in the country (Figure 3 ).

Figure 2. R\&D intensity by performing sector, Finland

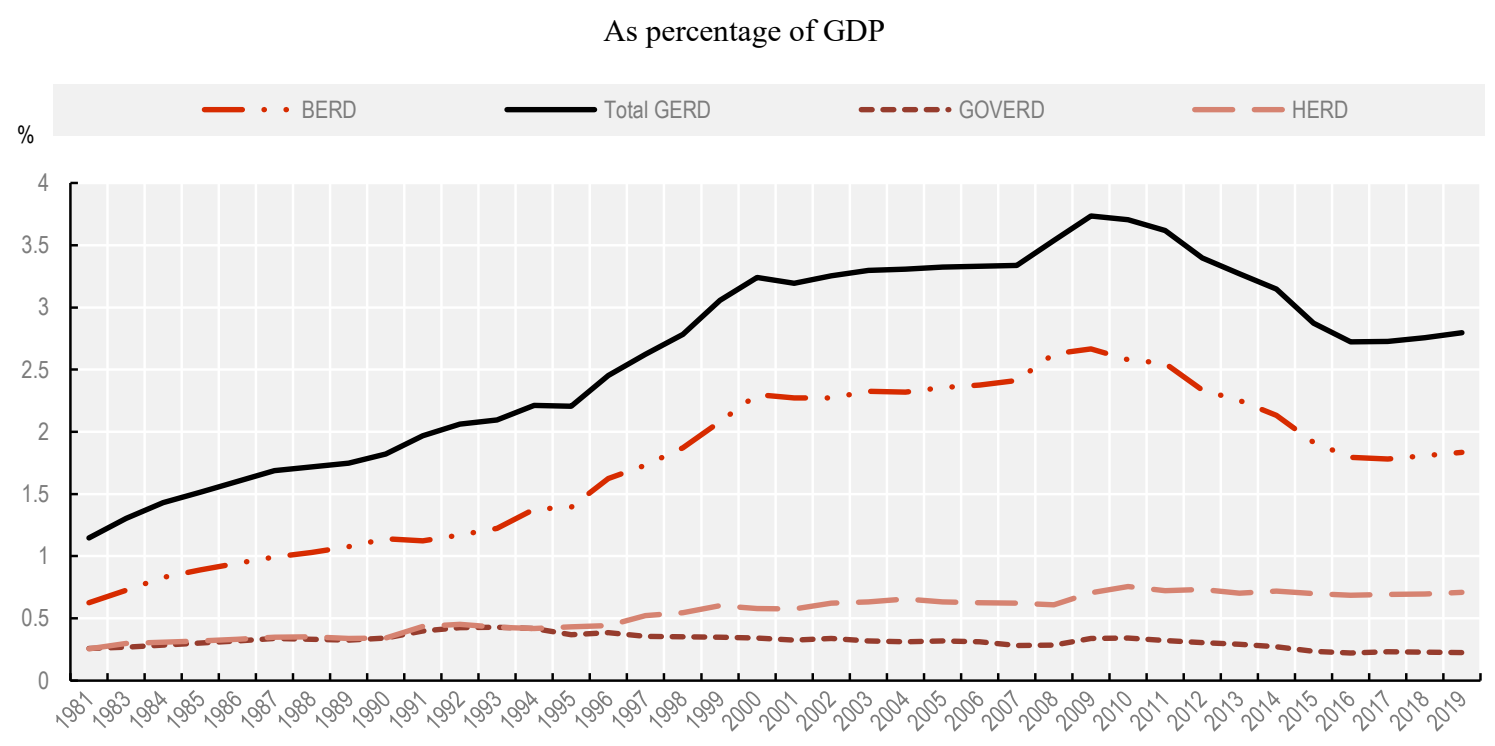

Note: The figure illustrates the evolution of the gross domestic expenditure on R\&D (GERD) in Finland (as a share of GDP) by performing sector: business enterprise sector (BERD), government sector (GOVERD) and the higher education sector (HERD).

Source: OECD (2021), "Main Science and Technology Indicators", OECD Science, Technology and R\&D Statistics (database), https://doi.org/10.1787/data-00182-en (accessed on 01 April 2021). 
Figure 3. BERD distribution by industry, 2017

Industry shares (left scale) and total BERD intensity (right scale)

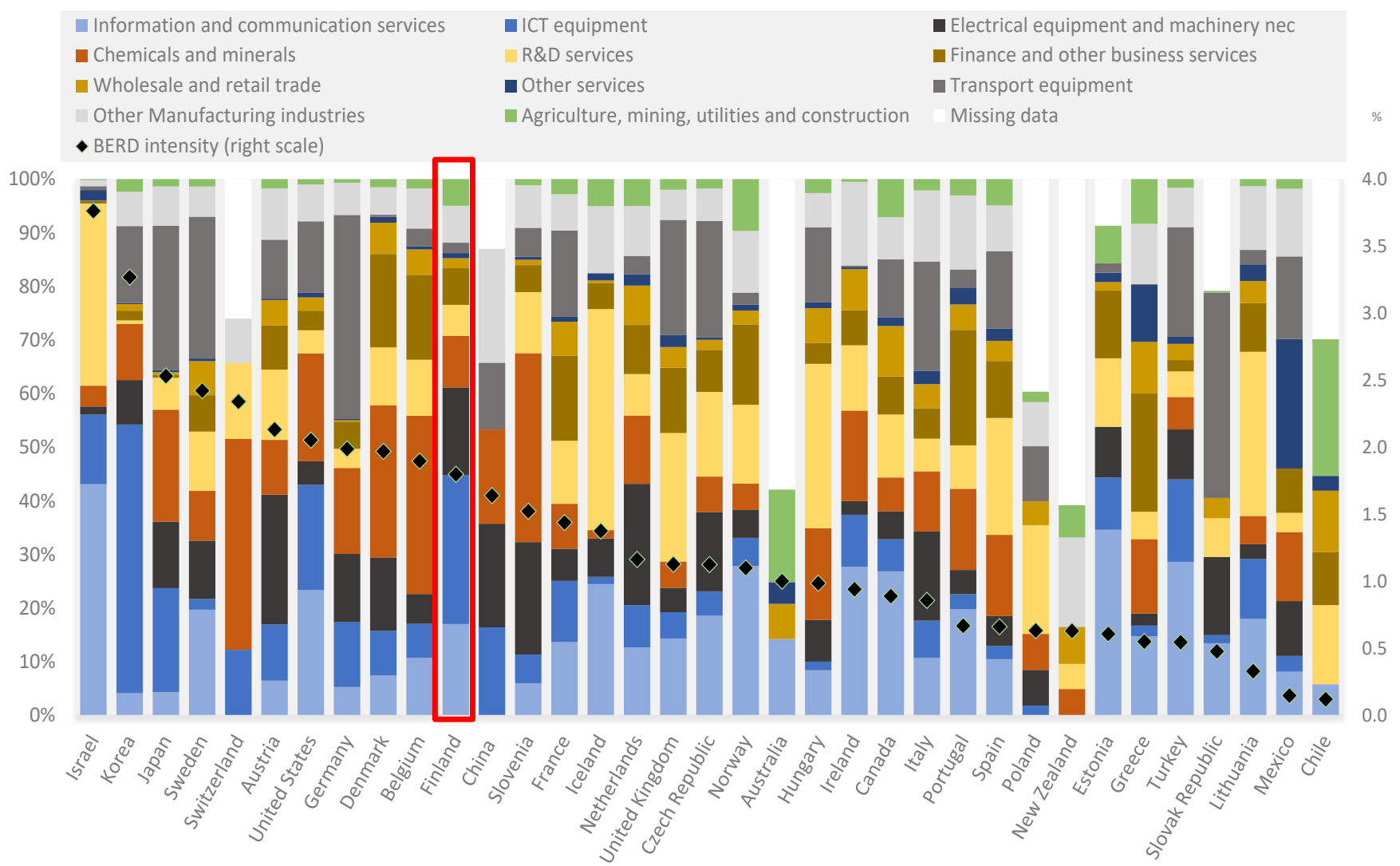

Note: 2017 or latest year available. ISIC Rev.4 divisions are as follows: Agriculture, mining, utilities and construction: 01-03, 05-09, 35-39 and 41-43; Chemicals and minerals: 19-23; Electrical equipment and machinery nec: 27-28; Finance and other business services: 64-66 and 69-82 excluding 72; ICT equipment: 26; Information and communication services: 58-63; Other Manufacturing industries: 10-12, 13-15, 16-18, 24-25 and 31-33; Other services: 49-53, 55-56 and 84-99; ISIC R\&D services: 72; Transport equipment: 29-30; and Wholesale and retail trade: $45-47$.

Source: OECD ANBERD database, http://oe.cd/anberd, November 2019, and OECD, Main Science and Technology Indicators Database, http://oe.cd/msti, July 2019.

\section{Structure of the study}

The remainder of the study is structured as follows. Section 2 presents the methodology. Section 3 explores the Finnish experience in setting targets to improve R\&D performance. Section 4 analyses the implementation of R\&D policies in Finland over time, focusing on lessons from successful and less successful policies, implementation challenges faced and how they have been addressed, and the role of policy versus other contextual factors as drivers of R\&D performance. Section 5 concludes with policy lessons and good policy practices. 


\section{Methodology}

The Finnish study focuses on the period spanning between 2005 - when the current $4 \%$ R\&D intensity target was set for the first time - and the present. It covers the policy target of R\&D intensity and other science, technology and innovation (STI) objectives directly linked to it. The innovation policy impact of the study is twofold: it highlights the lessons learned in Finland for other countries and makes policy recommendations for the future of the Finnish innovation system.

The methods used in the Finnish study were desk research, an online survey questionnaire with open questions and semi-structured interviews. The desk research included the indepth analysis of official reports that are publicly available, such as the minutes of the Research and Innovation Council (RIC) meetings and other key meetings within the government and ministries.

The R\&D intensity target questionnaire designed by the Organisation for Economic Cooperation and Development (OECD) was administered to four types of Finnish stakeholders: (1) Ministers and their advisors, (2) civil servants, (3) RIC members and (4) experts. They had the option to complete the survey online, via telephone or via a face-toface interview, or they could opt out. The survey could be answered in English or Finnish. In total 102 carefully selected stakeholders were contacted in the period 30/1-14/5/2020, with 2 survey reminders ${ }^{2}$. After regular survey reminders to all respondents and an additional email from the Technical Research Centre of Finland's (VTT) CEO to the seven current and former Prime Ministers ${ }^{3}$, 28 (15 surveys, 6 face-to-face interviews, 7 telephone interviews respondents) - including two Prime Ministers - participated in the study ${ }^{4}$. All telephone interviews and face-to face interviews have been recorded and transcribed, enabling further in-depth analysis based on the rich set of information obtained.

\footnotetext{
${ }^{2}$ The authors of this Finnish case study would like to thank all the interviewees for sharing their valuable insights.

${ }^{3}$ Finnish governments during the case study focus period listed in chronological order: Vanhanen I: 6.2003 - 4.2007; Vanhanen II: 4.2007 - 6.2010; Kiviniemi: 6.2010 - 6.2011; Katainen: 6.2011 6.2014; Stubb: 6.2014 - 5.2015; Sipilä: 5.2015 - 5.2019; Rinne: 5.2019 - 12.2019; Marin: 12.2019 present.

${ }^{4}$ The high response rate of $27.5 \%$ does cover sufficient diversity of respondents. The authors invited four types of respondents to participate in this study: (1) 20 ministers and their advisors (out of which 2 or $10 \%$ agreed to participate), 20 council members (out of which 4 or $20 \%$ agreed to participate), 32 civil servants (out of which 9 or $28 \%$ agreed to participate), and 29 external experts (out of which 13 or $45 \%$ agreed to participate). Given their extra busy schedules, response rates of Ministers and their advisors and of council members were lower than those of civil servants and external experts.
} 


\section{The Finnish experience with $R \& D$ target setting}

\subsection{Target setting}

Finland will soon have half a century of experience with national R\&D target setting and its implementation. In its early years, Finland was very successful in reaching R\&D intensity targets it had set, achieving them four times (see Figure 4). Today Finland has a national R\&D intensity target of $4 \%$ of GDP by 2030 , as set in government programs, issued twice in 2019 due to the change of Prime Minister (GP 2019a, 2019b).

Since the Great Recession that hit Finland exceptionally hard in the autumn of 2008, R\&D intensity target-setting and its implementation have been less ambitious and real commitment to achieving targets has weakened. The government has still set targets, explicitly or implicitly, but concrete actions to create a path to the targets were insufficient. Amid the current global COVID-19 turbulence, the R\&D target-setting lessons from the past can be vital for a long-term economic recovery.

Figure 4 illustrates the history of R\&D intensity target-setting in Finland. Starting in 1973 (see SPC 1973), the country has set a R\&D target for 10 times and is currently pursuing a target of $4 \%$ of GDP, to be reached by 2030 . After a challenging start during the oil crises of the economically turbulent 1970s, Finland performed well in reaching its R\&D targets between 1981 and 2004. As a result, innovation policy became a cornerstone of Finland's approach to enhance economic growth.

Building on the consistent development of the Finnish innovation system and policy schemes of the 1980s and $1990 \mathrm{~s}^{5}$, PM Vanhanen's government introduced for the first time the 4\% target in April 2005. The goal was realistic with respect to developments in the Finnish economy and the growth of R\&D expenditure since the late 1990s and with the latest intensity figure of close to $3.5 \%$, however driven by the large spending of only one sector, i.e. information and communication technologies (ICT), dominated by one company, Nokia.

While the ICT sector accounted for $27 \%$ of all R\&D in Finland in the mid-1990s, this share had peaked to $43 \%$ by 2008 , after which it fell back to $20 \%$ by 2018 (see Table 2 in Annex A for a summary of the sectoral $R \& D$ dynamics). Furthermore, the data show that these dynamics of the ICT sector were mainly driven by the gradual expansion and subsequent abrupt decline of Nokia. In 2000 Nokia represented $29.4 \%$ of all R\&D investments in Finland (Ali-Yrkkö \& Hermans 2002). By 2008, Nokia represented 2.6\% of GDP and $36.9 \%$ of total R\&D expenditures (Ali-Yrkkö 2010). While the role of Nokia for Finnish R\&D remained stable until 2009 a rapid decline took place as from 2012, and after the takeover of the Nokia Mobile Phones activities by Microsoft in 2013 Nokia's R\&D represented a mere $17 \%$ of the private R\&D investments in Finland (Ali-Yrkkö et al. 2013).

The new 4\% target was mentioned in the government's annual strategy document, which also offered a plan on how to reach the official objective. The target was linked to other

${ }^{5}$ Good examples were the Regional Centres of Expertise programme (OSKE 1994-2013), the Government additional appropriation programme of R\&D in 1997-1999 and the introduction of the national cluster programmes coordinated jointly by five Ministries in the late 1990s and 2000s (e.g. STPC 1996; Prihti et al. 2000). 
STI initiatives and development issues, and the government program of 2007 included a separate chapter on STI policy (see PMO 2005; PMO 2006a; PMO 2006b; GP 20076).

Finland's most innovation-friendly government programme (GP 2007) was launched in 2007, after which R\&D intensity reached its peak (3.73\%) in 2009. After that, the gap between the $4 \%$ target and real $R \& D$ intensity started to widen due to cutbacks in $R \& D$ investments made by ICT companies, mostly by Nokia, and as R\&D funding in the government budget began to decrease, and several R\&D and innovation instruments and programs were restructured or fully abolished.

Since 2005, the R\&D target has been left untouched at 4\%, with the exception of 20152017, when the objective was briefly abandoned (see Box 1). In 2019, the current government reintroduced the 4\% target to the government program (GP 2019a, 2019b).

\footnotetext{
${ }^{6}$ Actually, the first time the R\&D intensity target of $4 \%$ was mentioned in a policy-relevant paper was in June 2004, when the so-called Working Group on Globalisation (formed on the initiative of PM Vanhanen) stated in its interim report that public R\&D expenditure should be increased by $7 \%$ annually up to the end of the 2000s. The aim for increased public funding was to act as an incentive to raise R\&D intensity to at least $4 \%$. This was one of the key recommendations to enhance the competitiveness of the country and respond to recent challenges posed to Finnish work and production (PMO 2004a). The same proposal was made in the final report of the group in November (PMO 2004b). The proposal was further supported by Sitra (2005) in its innovation policy report in April 2005. This is how the $4 \%$ target started to gather momentum.
} 
Figure 4. Finland's R\&D intensity target changes and its performance in reaching the targets


The end of the target period has not been reached yet ${ }^{4}$

Notes:

${ }^{1}$ Based on the latest available Statistics Finland data on R\&D expenses and GDP at current prices (both series downloaded on 23.3.2020). The R\&D

intensity series for the even years from 1976 to 1996 are estimates based on an average of the nearest available data.

${ }^{2}$ One star indicates that the target appeared in a council document; Two stars indicates that the target appeared in a government's economic committee document or in a strategic government document but not in the government programme. Three stars indicates that the target appeared in the government programme.

${ }^{3}$ i.e. based on the original R\&D intensity data used at the time when policy lines and recommendations were originally drafted, but not any more after the GDP data was updated and recalculated later.

${ }^{4}$ Between 2015 and 2017 Finland had no R\&D intensity target at all, hence the two-year gap in the grey line.

Source: VTT, TEM, Statistics Finland.

As far as subnational targets at regional, local or sectoral levels are concerned, the R\&D target setting in Finland has happened at the level of the national government only. As the EU-wide R\&D target of 3\% leaves flexibility to its countries on how to reach that target, the Finnish target leaves flexibility to its industrial branches or regions on how to reach the 
national 4\% target. However, while no explicit targets on regional and sectoral levels have been set in Finland, policy documents very often have explicitly stressed a regional or sectoral focus, in terms of implementation of the national target (Wallin \& Laxell 2013; OSKE 2014) (For a description of regional R\&D see Annex 2).

\section{Box 1. Motivation and reasons behind the Finnish R\&D intensity target of $4 \%$ in 2005-2020.}

The Finnish R\&D intensity goal of 4.0\% was introduced for the first time in the Strategic document of PM Vanhanen's 1st government (2003-2007) on 7 April 2005. Initially, there were no specific preparatory policy papers made by the government or ministries behind the $4 \%$ target. Instead, the idea about the R\&D intensity target was first discussed in several high-impact policy reports published in 2003-2005 (e.g. STPC 2003; PMO 2004a, 2004b; Sitra 2005; Government 2005 prepared by STPC), and the goal was ultimately set at the political level (see also Footnote 4). The Government programme emphasised that economic growth and competitiveness would continue to be based on knowledge, utilization of new technology and advanced branding and commercialization activities.

The programme of PM Vanhanen's 2nd government (2007-2011) reinforced the goal of boosting resources in both the public and private sectors with a view to raise $R \& D$ funding to $4 \%$ of GDP. The aim was to strengthen innovation capacity by providing strategic inputs in selected areas (e.g. universities, SMEs, services, VC). Public Private Partnership (PPP) programmes were enhanced (the Centres of Expertise Programme OSKE, the Strategic Centres for Science, Technology and Innovation SHOKs; for more, see Chapter 4), a new university law enforced and a new university (Aalto University) created through a merger of three universities (technology, business, arts).

The programme of PM Katainen's government (2011-2015) stated that the 4\% target should be reached by the end the parliamentary term. The focus of funding was on universities, SMEs and growth companies ${ }^{7}$. The target was set by the previous government and discussed e.g. in the context of the Finnish Europe 2020 strategy in spring 2010. A bit later the same target was raised by the Government's EU Ministerial Committee and the RIC. Thus, it was not a surprise that the $4 \%$ goal found its way also to the next government programme.

After a long period of recession and slow economic recovery (in real terms, the volume of Finnish GDP did not reach the level of 2008 until 2017), the economic strategy that had earlier put an emphasis on the development of the innovation system and R\&D had vanished. This change was reflected in the programme of PM Sipilä's government (2015-2019) and other policy papers related to it, which did not set an R\&D intensity target. The government later acknowledged the need to refresh publicly funded R\&D (see Sipilä 2019), but the change of course fell short.

The significantly reorganized (2016) RIC $^{8}$ recommended in 2017 as part of the Council's STI Vision that the R\&D intensity target of $4 \%$ should be achieved by 2030 .

\footnotetext{
${ }^{7}$ In line with the original OECD and the EU definitions a growth company is defined as a business that initially employs at least 10 people and in which the average annual growth in the number of employees over the next three years is more than $20 \%$.

${ }^{8}$ RIC is chaired by prime minister and includes a broad composition of political decision-makers and the national innovation system's key stakeholders from public and private sectors. Until 2016, it did advise the government and its ministries in important matters in relation to steering and coordination of STI policy and prepared national plans. In 2016, RIC was dissolved and a new Council was established under the same name but with major changes made
} 
Once again, no planning papers or detailed minutes of the RIC talks concerning the $4 \%$ target exist. The government at the time did not react to the RIC's view, although it adopted a positive stance towards the OECD's (2017) review on the Finnish innovation policy, which emphasised the urgent need to raise R\&D funding.

The programmes of PM Rinne's (2019) and PM Marin's government (2019-2023) stated that RDI investments would be put on a growth track. A specific roadmap for the government prepared by the Ministry of Education and Culture (MEC) and the Ministry of Economic Affairs and Employment (MEAE) was published in April 2020 with a view to raise RDI investments to $4 \%$ of GDP by 2030 and to enhance the (PPP-based) environment for innovation and experiments. However, it remains to be seen to what extent the ongoing COVID-19 crisis will encourage the implementation of the longterm investments that Finland needs in order to absorb future economic and societal shocks.

\subsection{Target criteria}

While R\&D intensity is often considered a path dependent indicator, the criteria used to determine specific R\&D targets can vary over time, as the Finnish case demonstrates. The essential spark leading to the first target set in 1973 came from the realisation that Finland was clearly lagging behind its Western neighbours. Gradually but steadily, the original target of $1.7 \%$ (that was to be reached by 1980) was raised with the aim to further catch up with peer countries. Eventually, the aim became more ambitious, seeking to score higher on the rankings of World Economic Forum, Institute for Management Development (IMD) and European Innovation Scoreboard, and to reach the top countries in the late 1990s and to maintain that position. According to the interviewees, in the first half of $2000 \mathrm{~s}$, the aim of the ambitious R\&D targets was to become the most competitive and the most technology-intensive country in the world. The criteria and reasons for target-setting between 2005 and the present are summarised in Box 1.

While the rationale and criteria to set the targets were the fruits of genuine understanding, interaction and commitment, by 2011 increasingly ambitious targets were not matched by specific actions. The situation became more challenging when Government R\&D spending, in the challenging aftermath of the Great Recession, shifted from counter-cyclical to procyclical after 2011 (see Figure 4). The goal was to produce similar R\&D-driven positive impacts that were observed in the context of the Finnish recession in the 1990s. However, the economic scene had changed, and the translation process of research into innovation had become more cumbersome.

After the decline of Nokia's mobile phone business and the Finnish ICT sector during 2009-2013, there were no other globally significant "locomotive enterprises" or ecosystem leaders that could have acted as R\&D intensive appliers of new knowledge. The industryacademia collaboration culture eroded, and the central administration's instruments (incl. SHOKs; OSKE and its successor the Innovative Cities Programme INKA; see Chapter 4) that previously had incentivised multilateral PPP cooperation were terminated suddenly in 2015. Consequently, firms' will to fortify their competitiveness through R\&D weakened. In addition, numerous policy reports and evaluations transmitted the same message: the volume of R\&D investments made by both the public and private sectors were in decline and PPP-based multilateral cooperation was getting weaker (e.g. OECD 2017; EC 2017, 2018).

to the composition, mandate and modes of operation (see also Chapter 4 and Borowiecki \& Paunov 2018). 
Moreover, an erosion of institutional memory ${ }^{9}$ within the innovation system's key policy organisations, such as the Government, ministries and RIC, also affected the country's ability to reach $R \& D$ targets.

\subsection{R\&D intensity as an indicator of innovation activity}

The majority of interviewees considered R\&D intensity to be an acceptable measure to capture innovation activities in Finland. However, they argued that instead of having one measure, it would be important to have a set of measures complementing each other, including a set of sub-measures decomposing the R\&D intensity. Finnish interviewees believed that the main value of the R\&D intensity target is political in the sense that it raises the political attention to the importance of investments in the entire innovation system what may be helpful for getting funding for private and public R\&D. As with all measures, the indicator has strengths and weaknesses.

The R\&D intensity indicator has multiple strengths, as identified by the respondents:

- It is a simple measure and it gives the best possible available idea of the overall orientation of both $\mathrm{R} \& \mathrm{D}$ and innovation (RDI).

- It is understandable and acceptable for decision makers to use it and to communicate about it.

- The indicator is widely used and is a "familiar policy target".

- It is easy to retrieve from statistical offices.

- It is a statistical measure that is internationally comparable.

- In the long-term the measure shows the relative direction of the country's added value.

- Changes to the measure indicate the direction of the country's innovation investments.

The Finnish interviewees also identified several weaknesses in the indicator:

- The measure can be easily misleading. According to the respondents, instead of using this input measure of innovation it is better to consider the composition of the R\&D inputs (e.g. research versus development, quality of the research projects $)^{10}$ and the efficiency in reaching impact simultaneously. The relevance and effectiveness of R\&D in Finland should be evaluated and according to best practice this should be done by external top experts.

- The measure has a bias for certain technologies and sectors. That is why comparisons to peer countries have to be made over time taking into account the economic, industrial and societal structures.

\footnotetext{
${ }^{9}$ Institutional memory or social capital refers to individuals' and organisations' understanding of STI policy measures and objectives, awareness of (long-lasting) good policy practices and willingness to follow well-tried procedures, and to determined aspiration to create and enhance partnerships between various stakeholders within the innovation system and across different fields of administration.

${ }^{10}$ On the importance of distinguishing between research and development see Becker et al. (2020) and on the role of quality of R\&D projects see Huenermund \& Czarnitzki, (2019).
} 
- It is not clear-cut how this R\&D input measure relates to innovation output. The concern is that $R \& D$ is not as much related to innovation as one might think.

- The measure is narrow as it does not capture investments in all intangibles, such as some investments in software.

- The indicator should be broken down into its components - e.g. share and volumes of each sector, universities, polytechnics and government R\&D institutes separated, enterprise sector broken down by fields of industry, size of companies - as to provide better insights into the relative strength of R\&D performers and challenges of achieving the $R \& D$ intensity target.

\subsection{Specific indicator challenges to measure business-led innovation}

It turns out that $R \& D$ intensity has specific shortcomings in measuring business-led innovation (see also Mohnen 2019). It was highlighted by the interviewees that:

- By construction the measure does not include the R\&D of start-ups with less than 10 employees, although many of these small firms may still have a high R\&D intensity. Despite Finland's relatively smaller share of start-ups and young firms among micro-firms (2-9 employees), and despite its lower entry and exit rates than the benchmark (OECD 2020), this indicator challenge can be especially relevant for Finland as it experienced a boom of tech-based start-ups during the 2010s, driven in part by ex-Nokia employees and tech-savvy graduates

- Reporting the R\&D of the firm should not reveal any information that could harm competitiveness. In this sense some firms may under-report their R\&D.

- The indicator actually measures spending on R\&D, but externalities and spillovers and long-term effects are not taken into account, which may well lead to wrong conclusions and inferior policy decisions. For instance, some R\&D activities may generate wider public benefits and benefit innovation, depending on the nature of the R\&D or the way the R\&D activities are connected to innovation activities.

- Understanding innovation processes is essential as they vary between firms and sectors and affect the amount and type of inputs that are needed. Just the amount of R\&D funding does not say anything about those differences.

- Changes in the content of innovation activities should be measured more accurately; for example, the measure may not fully capture business R\&D due to digitalisation.

- The available statistics have several weaknesses: they use outdated sector classifications, it is difficult to make decisions based on statistics, there are sampling issues, suboptimal definitions are used, and the interpretation of survey questions can vary.

- Innovation in services and non-technological content may also be inadequately identified by the available indicators.

- It is more important to measure RDI outputs and wider impacts than to measure inputs. However, it is hard to find or construct workable output and impact indicators. 


\section{The Finnish experience implementing R\&D targets and policies}

\subsection{STI Policy background}

Finland's rise to the forefront of productivity and ICT-related technological development in the latter half of the 1990s happened rapidly but would not have been possible without long-term determined investment in education, human capital and skills.

In the late 1990s, STI policy became the cornerstone of the national economic strategy ${ }^{11}$. Both the private and the public sector invested in R\&D, innovations and in the utilisation of new technological opportunities. Growth rates of $R \& D$ expenditure were record high: between 1995 and 2000, growth was 128\% in the business enterprise sector and 64\% in universities (in nominal terms). At the same time, government's direct budget R\&D funding increased by $39 \%$.

In the 2000s, a high-quality education system and innovativeness became key components of Finland's national image both at home and abroad (see Table 1 with a synthesis of the Finnish STI policy in 2005-2020). Long-lasting favourable development of the economy and productivity growth supported the belief in consistent investments in R\&D and skills. This belief rested on Finland's good performance in international innovation and competitiveness rankings. Finland was $1^{\text {st }}$ or $2^{\text {nd }}$ in World Economic Forum's Competitiveness comparisons in 2001-2005 and among the top five countries in IMD's competitiveness comparison in 1997-2003 (see Pajarinen et al. 2017). Rankings remained strong until the onset of the $2010 \mathrm{~s}$, despite the economic and employment slowdown that had already started by that time.

11 This trend of R\&D and innovation being in the centre of the national strategy achieved its culmination first in the government programme of PM Paavo Lipponen's second cabinet (1999) and then in the government programmes of PM Matti Vanhanen's second cabinet (2007) and PM Jyrki Katainen's cabinet (2011). In all these programmes, there are multiple references to 'research/R\&D' and 'innovation'. Also the current government programme of PM Sanna Marin's cabinet (2019) reaches the same reference level. 
Table 1. Development from ST policy to RI policy in Finland in 2005-2020 (until COVID-19 crisis)

\begin{tabular}{|c|c|c|c|}
\hline Period & $\begin{array}{l}\text { From responding to globalization and harder } \\
\text { international competition to financial crisis and its } \\
\text { impacts (2005-2011) }\end{array}$ & $\begin{array}{l}\text { The Finnish economy declines; belief in R\&D and } \\
\text { innovation driven growth wanes (2012-2017) }\end{array}$ & $\begin{array}{l}\text { From readjustment of the Finnish economy and } \\
\text { innovation system towards new research and } \\
\text { innovation policy (2017- 2020) }\end{array}$ \\
\hline $\begin{array}{l}\text { Framework } \\
\text { conditions for } \\
\text { policy }\end{array}$ & $\begin{array}{l}\text { The economy grows until the financial crisis hits in } 2008 \text {. } \\
\text { In } 2009 \text {, the ICT and forest sectors shrink quickly, which } \\
\text { has long-term economic impacts; the government } \\
\text { makes counter-cyclical actions (e.g. more R\&D funding). }\end{array}$ & $\begin{array}{l}\text { Prolonged recession until 2016. Roles and impacts of } \\
\text { R\&D and innovation are challenged by decision-makers. } \\
\text { Policy lessons of the 1990s recession do not receive } \\
\text { positive responses anymore, and balancing public } \\
\text { finances leads to cuts in R\&D funding. }\end{array}$ & $\begin{array}{l}\text { Strengthening new growth and economic sustainability; } \\
\text { boosting competence- and technology-based } \\
\text { comparative advantages; To some extent, } R \& D \text { and } \\
\text { innovation regain their place at the centre of economic } \\
\text { development and productivity. }\end{array}$ \\
\hline $\begin{array}{l}\text { Government } \\
\text { policy goals }\end{array}$ & $\begin{array}{l}\text { Comprehensive development of the innovation system. } \\
\text { Reduction of systemic fragmentation. Several structural } \\
\text { reforms, incl. university reform. Fortifying the role of high } \\
\text { technology and ICT in the economy and exports. }\end{array}$ & $\begin{array}{l}\text { Economic growth; reduction of unemployment; research } \\
\text { institute and funding reform; supporting knowledge- } \\
\text { based decision making and new growth; emergence of } \\
\text { grand challenges to the policy agenda. }\end{array}$ & $\begin{array}{l}\text { Identifying and supporting new growth areas; growing } \\
\text { number of innovative growth firms; export promotion; } \\
\text { responding to societal challenges as one of the main } \\
\text { goals of innovation policy. }\end{array}$ \\
\hline $\begin{array}{l}\text { STI policy } \\
\text { priorities and } \\
\text { approaches }\end{array}$ & $\begin{array}{l}\text { Gradual rise of broad-based innovation policy to replace } \\
\text { traditional S\&T policies. Innovation policy becomes a } \\
\text { focal element of the Government Programme (2007). } \\
\text { MEAE's Action plan for demand- and user-driven } \\
\text { innovation policy }(2010-14) \text {. }\end{array}$ & $\begin{array}{l}\text { Strategic choices made in Government Programmes; } \\
\text { ramping-down of centres of excellence and PPP } \\
\text { network instruments (SHOK 2015, INKA 2017), RDI } \\
\text { policy's focus areas include arctic expertise, bio, } \\
\text { cleantech, digitalisation, health, and nanotechnologies. }\end{array}$ & $\begin{array}{l}\text { Innovation-based growth; new PPP cooperation and } \\
\text { ecosystems (re-)appear on the government's policy } \\
\text { agenda; new partnership models are being drafted; } \\
\text { promotion of horizontal innovation policy; new mission- } \\
\text { driven policy openings. }\end{array}$ \\
\hline $\begin{array}{l}\text { Volume of } \\
\text { R\&D } \\
\text { expenditure }\end{array}$ & $\begin{array}{l}\text { Companies' R\&D spending grows rapidly (+32\% in } \\
2005-08) \text {, driven by ICT-sector, and then stops } \\
\text { suddenly in } 2009 \text {. Government R\&D funding grows by } \\
4 \% \text { a year in } 2005-11 \text {. After } 2011 \text {, both private and } \\
\text { public R\&D financing are on a downward trend. }\end{array}$ & $\begin{array}{l}\text { Decades-long growth of R\&D funding ends. Especially } \\
\text { government R\&D institutes and Tekes suffer from } \\
\text { budget cutbacks, and multilateral cooperation fades. } \\
\text { R\&D funding dips for } 5 \text { years in a row (2011-2016): in } \\
\text { real terms this represents a total drop of } 19 \%(29 \%) \text { in } \\
\text { public (private) funding. }\end{array}$ & $\begin{array}{l}\text { Private and public R\&D starts to recover. From } 2016 \text { to } \\
2019 \text {, volumes of private } R \& D \text { expenditure }(+10.3 \%) \text { and } \\
\text { government } R \& D \text { funding }(+9.4 \%) \text { grow, but intensity } \\
\text { figures are stable with } 2.7 \% \text { recorded for total } R \& D \\
\text { intensity and } 0.8 \% \text { related to public } R \& D \text { funding. }\end{array}$ \\
\hline $\begin{array}{l}\text { National R\&D } \\
\text { intensity target }\end{array}$ & $\begin{array}{l}\text { In April } 2005 \text { government sets R\&D intensity target of } \\
4 \% \text { of GDP for the year 2009. Intensity reaches its all- } \\
\text { time peak in } 2009 \text { ( } 3.73 \%) \text {. After that, R\&D intensity } \\
\text { started to decrease and did not stabilize until } 2016 / 2017 \\
\text { at the level of } 2.7 \% \text {. }\end{array}$ & $\begin{array}{l}\text { Governments of PM Katainen (2011-14) and PM Stubb } \\
\text { (2014-15) reinforce the } 4 \% \text { target. Without public notice, } \\
\text { RIC abandoned the goal in } 2012 \text { as it was considered to } \\
\text { be out of reach. PM Sipilä's government (2015-19) did } \\
\text { not set any R\&D intensity goals. }\end{array}$ & $\begin{array}{l}\text { In } 2017 \text {, re-created RIC chaired by PM sets a } 4 \% \\
\text { intensity target (by 2030), which runs against the } \\
\text { essence of the then government programme. Before } \\
\text { general elections in 2019, almost all parties supported } \\
\text { the } 4 \% \text { goal. New government reinforces the target in } \\
2019 \text {. }\end{array}$ \\
\hline $\begin{array}{l}\text { Essential } \\
\text { policy tools } \\
\text { and new } \\
\text { instruments }\end{array}$ & $\begin{array}{l}\text { Various networking activities; Strategic Centres of } \\
\text { Excellence in Science and Technology (SHOKs) } \\
\text { launched in 2006; Regional Centres of Expertise } \\
\text { programme (OSKE) (1994-2013). }\end{array}$ & $\begin{array}{l}\text { Innovative Cities programme INKA (2014-17); } \\
\text { Government's TEAS projects supporting decision- } \\
\text { making; Strategic Research Council (2014-); Tekes' } \\
\text { tools expand to cover activities like venture capital; R\&D } \\
\text { tax incentive only briefly (2013-14) in place. }\end{array}$ & $\begin{array}{l}\text { Updating the policy toolbox (incl. application of previous } \\
\text { well-working cooperation and programme practices); } \\
\text { RDI-friendly public procurement; innovation voucher; } \\
\text { Government's RDI Roadmap (2020) introducing new } \\
\text { potential policy measures. }\end{array}$ \\
\hline
\end{tabular}


A major overhaul of the structures and funding of the innovation system started to unfold by 2010 with the aim to increase both research efficiency and social relevance. The state's commitment to the long-term development of research and innovation was based on the Government Resolution on the Structural Development of the Public Research System (see PMO 2005). This resolution, published on April 2005, helped spark a wave of significant renewals in the Finnish innovation system in 2006-2010.

As was briefly mentioned in section 3.1 , the rapidly increasing R\&D intensity since the 1990s was vigorously driven by the ICT sector with the lead of Nokia. While the ICT sector accounted for $27 \%$ of all R\&D in Finland in the mid-1990s, this share increased to over $40 \%$ by the mid-2000s. It was clear that the entire innovation system was heavily and even alarmingly driven by the ICT sector in general, and Nokia in particular. Towards the end of 2000 s, ICT accounted for $43 \%$ of the total R\&D work and almost $60 \%$ of the business enterprise sector's R\&D expenditure in Finland. The slowdown began during the financial crisis in 2009, but the business stayed strong: in 2008, Nokia accounted for $39 \%$ of the world's mobile markets, and in 2010 it was still a big player with a market share of $29 \%$. After Nokia sold its insolvent mobile business to Microsoft in 2013, R\&D intensity dropped, and the volume of R\&D investments by the manufacturing sector took a record dive with almost EUR 1.4 billion in cutbacks made in Finnish industry in five years $(-35 \%)$.

Following the great recession, new economic growth ambitions in the 1990s and 2000s were focused on the diversification of the industrial base and later on the support of seed stage, start-up and growth enterprises and SME exports in the form of increasing public venture capital investments and promotion of internationalisation. The need to diversify the industrial base related to the fact that the economy was greatly dependent on the forestry, metal-related industries and the ICT sector, while there wasn't any other rapidly growing or emerging industrial field developing. For example, in 2000 the fields of ICT, electronics and forestry accounted for almost $60 \%$ of the total value of product exports. The policy goal was to spur companies in all major fields of industry to grow more quickly and enter foreign markets with the help of public R\&D support (see e.g. Dahlman et al. 2006 for a comprehensive review of the Finnish economy and the changes of the industrial structure in the 1990s and early 2000s).

By the mid-2010s, a view spread among policymakers that the reforms of structures of the innovation system carried out in previous years (e.g. university reform and mergers of universities, renewals in the government R\&D institutes, establishment of SHOKs, extension of Tekes' duties beyond R\&D and innovation) were not helpful enough to maintain Finland's good position in international markets and competition and to push the country out of the prolonged recession in the first half of the 2010s.

The situation became more uneasy due to cutbacks in the government's R\&D budget that started in the beginning of PM Katainen's government term (-12\% from 2011 to 2015, in real terms). The biggest cut was made ( $-8.5 \%$ in just one year) at the onset of PM Sipilä's Government (2015-2019). A part of this cut was compensated during the rest of the PM Sipilä's government term, but in real terms the volume of the R\&D budget in 2019 was still $5 \%$ lower than it was at the beginning of the term. This, together with the events and renewals of the previous electoral period, led to a significant change of direction of STI policy when seen against earlier developments (see Koski et al. 2019). 


\subsection{STI Policy Reforms and Initiatives}

\section{The Centre of Expertise Programme}

The Centre of Expertise Programme (OSKE), which supported regional innovation from 1994 to 2013, has been the most important tool for regional innovation policy in Finland. The OSKE directed activities to areas of national importance and supported cooperation between research and business. The idea behind the programme was to promote the utilisation of internationally top-level expertise based on regional strengths. The OSKE covered three programme periods (1994-1998, 1999-2006 and 2007-2013) and in the final period, cluster-based cooperation was developed in 13 different focus areas (see OSKE 2014).

\section{The Innovative Cities Programme (INKA)}

The experience gained from the OSKE was utilised in the Innovative Cities Programme (INKA 2014-2017). It stressed the role of cities in building regional innovation hubs: the goal was to create more attractive, globally networked hubs in urban areas. Unfortunately, as part of the budgetary cutbacks in 2015, the Government decided to phase out the INKA programme by 2017. As a counterbalance to this, an increasingly large portion of the EU Structural Fund assets in the funding period 2014-2020 were allocated to R\&D, technology and innovation. The aim was to have better policy instruments to channel national and regional resources into more strategic and broader development entities, including international networking.

\section{The Strategic Centres for Science, Technology and Innovation (SHOKs)}

The objective of the SHOK ${ }^{12}$ initiative, initiated by the RIC in June 2006 and created 20072009, was to enhance RDI-driven business and to renew the business enterprise sector in Finland by creating new competitive advantages both at organisational, cluster and system levels. SHOK activities aimed at introducing a new PPP type of cooperation and interaction as well as testing new kinds of collaborative platforms and environments. The basic idea was to have both enterprises and research organisations carry out research based on a jointly drafted research agenda and with a view to produce concrete innovations and business models in 5-10 years time. Thus, initially SHOKs had long-term perspective on RDIdriven development, and gradually SHOKs became one of the principal instruments of Finnish innovation policy. It can be estimated that the volume of SHOK funding totalled over EUR 600 million in 2008-2015. On average, 60\% of this funding came from Tekes (now Business Finland, BF) and 40\% from enterprises involved in the SHOK projects. At its largest, Tekes committed up to one fourth of their annual funding through the SHOK programmes (see e.g. STPC 2006; Lähteenmäki-Smith et al. 2013; Piirainen et al. 2019).

\section{The university reform}

Reforms of universities and universities of applied sciences were carried out in 2010 and in 2014-2015 respectively. The key objectives of these reforms were to strengthen economic and administrative autonomy, add flexibility to personnel policy, diversify the

\footnotetext{
${ }^{12}$ The SHOKs refer to six companies and their areas of expertise. The SHOKs were: Metal products and metal engineering, FIMECC Ltd (currently DIMECC Ltd); Built environment innovations, RYM Ltd; Energy and the environment, CLEEN Ltd (currently CLIC Innovation Ltd); Information and communication industry and services, TIVIT (later DIGILE Ltd, currently DIMECC Ltd); Forestcluster (later Finnish Bioeconomy, FIBIC Ltd, currently CLIC Innovation Ltd); Health and wellbeing, Salwe Ltd.
} 
financial base, and to improve the conditions for cooperation and profiling between universities (Wennberg et al. 2018). In addition to detaching universities from the state and transforming them into independent legal entities under either public law or the Foundations Act, the aim of the reform was to enhance universities' preconditions to restructure activities and resources more on the fields of comparative strength (profiling) and to increase universities' involvement in multilateral interaction. Unfortunately, according to various evaluations the progress made in these issues has been comparatively slow (see Hjelt et al. 2018; Owal Group 2016; Wennberg et al. 2018) ${ }^{13}$.

\section{The $R \& D$ institutes reform}

Starting in 2013 the public R\&D institutes and their research funding scheme underwent a reform. Some of the state's research institutes were merged into larger entities or incorporated into a university. As a result, the number of state R\&D institutes decreased from 20 to 12 in 2015. Due to the reform and other government decisions, R\&D institutes' budgetary research funding dropped between 2013 and 2016 by $37 \%$ to EUR 197 million (Haila et al., 2018). Alongside these reforms, the Technical Research Centre of Finland (VTT) strengthened its role in research and innovation that aims to respond to social, economic and other grand challenges (Hjelt et al. 2019). Two cornerstones of this reform included: (1) the establishment of a financial instrument, managed by the Strategic Research Council (SRC), in connection with the Academy of Finland (i.e. Research Councils Finland) in 2014 and; (2) strengthening of the analysis, assessment and research activities (VN TEAS) that support the Government's decision making (Finnish Government 2013). The reform's unwanted consequences have received ample attention (Haila et al. 2018; most recently Ormala 2019 and Koski et al. 2019). In 2019 the sector's combined volume of public R\&D budget funding was 47\% smaller than in 2011 (in real terms), declining from EUR 304 million to 184 million (in nominal terms).

\section{The Research and Innovation Council (RIC) reform}

The original RIC that was established in 1987 held its last meeting in December 2014, soon after the Council adopted its final extended STI policy review. Over the years, the RIC functioned mainly as a forum for wide discussions on alternative policies and priorities and aimed at forming national strategic consensus on the most essential policy issues. This was linked with monitoring the state and effectiveness of the innovation system as a whole. The re-creation of the RIC took place in April 2016 and it entailed a few major changes: (1) The RIC became much smaller. The Council was still chaired by the Prime Minister, and its members now were the Minister of Education and Culture, the Minister for Economic Affairs, one other minister appointed by the Government and five other members representing research and industry. (2) The Council's independent secretariat and the two subcommittees were abolished and preparatory work was assigned to a group of civil servants from the Ministry of Education and Culture, the Ministry of Economic Affairs and Employment, the Prime Minister's Office, Tekes/Business Finland, and the Academy of Finland (see OECD 2017).

The nature of Council's efforts and the way their work has been organized has changed significantly since 2016. In addition, most of the recommendations made in the independent

13 During the years 2015-2019, EUR 50 million was transferred from the state funding for universities to the competitive funding of the Academy of Finland. It was evaluated that funding did not in essence lead to strengthened cooperation between universities. However, the funding was perceived as a good tool to get strategy messages through the organisation and it enabled more agile development within universities (see Hjelt et al. 2018). 
evaluation of the RIC published in Spring 2014 (Pelkonen et al. 2014) were not put into practice $^{14}$, and the RIC activities in 2016-2019 were not as intensive and independent as earlier (see Lemola 2020). This is also reflected in the Council's meeting minutes (see RIC 2020). However, one bullet point of the Council's eight-slide Vision 2030 presentation in 2017 stated that the Finnish public and private sector together should invest $4 \%$ of GDP in RDI activities. This target is still topical and included in the current government programme.

\section{The merger of Tekes and Finpro}

In the latest structural reform, Tekes (the Finnish Funding Agency for Innovation) and Finpro (provider of internationalisation advisory services) merged into Business Finland in 2018. The aim was to clarify and simplify the enterprise service system, internationalise the innovation system, and strengthen the exports and internationalisation of SMEs. In order to ensure the expediency of the reform and to identify the needs for change the Ministry of Economic Affairs and Employment launched an independent evaluation of Business Finland in January 2021. The assessment, due to be completed in summer 2021, will specifically address Business Finland's role, position and impact as well as its operating model and performance.

\section{Other initiatives}

In recent years, several initiatives listed below aimed at increasing the quality of R\&D and the effectiveness of public RDI funding (e.g. AF 2020a; BF 2020; see also Table 1):

Funding instrument for challenge-driven research: Business Finland's 'Challenge Finland' was the funding programme (EUR 22 million in 2017-2018) for promoting the emergence of radical innovations.

Development of innovation capacity and commercialisation activities in research organisations: Business Finland's 'Innovation Scout'/KINO programme 2015-2017. The volume of funding channelled through the programme was EUR 7.2 million. It was linked to the TULI-programme 'Creating Business from Research' that started in 1993 and is still on-going, albeit after several redesigns, under the present name of Research-to-business. In 2012-2017, the volume of funding channelled through the programme was some EUR 138 million (Valtakari et al. 2018).

Development of enterprise-driven business ecosystems: Business Finland's 'Growth Engines' funding (EUR 60 million in 2018-2019) aimed at creating PPP-based cooperation networks to support new business activities that strive e.g. to create new growth sectors.

\footnotetext{
${ }^{14}$ The evaluation states that RIC still has an important role as a body that brings together politicians and experts and that its key impacts are seen in government programmes, R\&D funding and the significance of R\&I issues on the political agenda. At the same time, it was seen that RIC has lost some of its position and effectiveness, it does not have a particularly strong position in horizontal policy and that it works quite reactively. Consequently, to meet the needs of a changing operating environment, RIC's operating methods should be renewed. The key recommendations include: (1) RIC needs more strategic activities that draw systematically on foresight and assessments; (2) RIC should rely more on external experts and stakeholders; (3) sectoral ministries should become more involved in the RIC's work; (4) interaction, transparency and communication of RIC's operations should be reinforced; (5) RIC's subcommittees should be replaced by thematic drafting bodies or working groups; (6) RIC's resources must be increased; (7) RIC's secretariat could be placed in the Prime Minister's Office, thus stressing RIC's horizontal and strategic position. From all of these, only proposal four was partly put into practise when the new RIC was re-formed in 2016. Eventually, the renewal of RIC and its motives were mostly reflecting discontinuities in the STI policy making and the changes in power relations within the central administration and between ministries (see e.g. OECD 2017; Akava 2017; Leppälahti 2018).
} 
Flagship Programme (Academy of Finland) for academic centres of expertise provides long-term funding for large flagships/ecosystems (currently 6), each operating in their specific field. It promotes cooperation between research, business and society, and helps to create solutions to societal challenges and develop new business opportunities. Over the period 2019-2022, total funding will be some EUR 320 million, of which the Academy's share will be over EUR 54 million.

Research Infrastructure Committee, which has financed the construction and upgrading of research infrastructures with EUR 18.5 million a year. In 2013-2017, jointly with other funders, this has made it possible to channel EUR 500 million for the development of national and international research infrastructures (AF 2020b).

Establishment of the network-based Competence Centre for Sustainable and Innovative Public Procurement (KEINO). The main objectives of this centre of 14 experts and their six background organisations (e.g. BF, VTT) are the following: the number of innovative and sustainable procurements will increase; public procurement will be recognized and actively used as a management tool; and that contracting entities will disseminate information about their own experience and learn from one another. The value of public procurements is some EUR 35 billion a year (appr. 16\% of GDP) (KEINO 2020).

In addition, the Ministry of Education and Culture and the Ministry of Economic Affairs and Employment published in April 2020 a new RDI roadmap compiling a set of initiatives on how to support the government's STI policy objectives and R\&D intensity target of 4\% (RDI Roadmap 2020).

\subsection{Successful policies: changes in governance and turns in policy-making}

The policies that were the most and least successful in driving R\&D intensity in Finland were identified based on the opinions of interviewees in line with existing evaluation studies. However, as several of the available evaluations are not 'independent' not surprisingly the quality of the evaluations has been heterogeneous ${ }^{15}$. The opinions of the respondents sometimes differed on what constituted a success and a failure. Some policy initiatives were indeed seen both as successes and failures. Based on the interviewees' opinions the consensus on key initiatives and their mechanisms is summarised below.

The establishment of the National Technology Agency (Tekes) in 1983 was an important milestone for the Finnish Innovation System and R\&D target setting. The set-up of Tekes was part of a broader Finnish strategy focusing on investments in knowledge and technology, and initially driven by visionary members of the Technology Committee, including wide-ranging representation from the public administration, the business enterprise sector and STI community (Committee Report 1980). The committee was initially an Automation Committee with the task to find measures to prevent negative impacts of automation technologies on employment and other social consequences. But during the course of their work, the approach was changed, since it was seen that the enhancement of automation and other technological development would actually lead to greater economic growth and better employment. Furthermore, the founding of Tekes was not the actual objective of the Committee, but it certainly accelerated its establishment by making recommendations on increasing resources for technical education and research (Lemola 2020). Eventually Tekes was a success because over time it served as a driver of

15 The gold standard for evaluations are broad-based evaluation panels of foreign top experts such as the one undertaking the evaluation of the Finnish innovation system in 2008-2009 (Veugelers et al. 2009a, 2009b). 
change. The overarching long-term approach of Tekes was to invest in capabilities. This turned out to be of strategic importance with success stories in ICT, gaming and carbon neutrality.

Initially the Tekes' funding was taken care of in a way that allowed it to: (1) interact with customers, (2) have the freedom to develop its own processes and (3) build everything itself. As a result Tekes' national technology programs in the 1980s were the first instruments to stimulate collaboration between different stakeholders and were - and this is of fundamental importance - from the outset co-created with industry.

The programs marked the start of a strong collaborative Finnish culture. Industry-academia collaborative projects from the $1980 \mathrm{~s}$, in the form of the first wave of the national technology programs, were renewed in the 1990s and early 2000s. Especially in the latter part of the 1990s, the ground-breaking technology programs of Tekes, research programs of the Academy of Finland, and the jointly designed and implemented programs by Tekes and the Academy became important in driving R\&D intensity, but this collaboration started to diminish by the early-2000s.

In 1996, state property was sold and a part of these funds were used (based on government economic policy committee's decision in September 1996) to launch a specific additional appropriation programme for R\&D to be implemented in 1997-1999. Nonetheless, the attitude towards major increases to $R \& D$ and innovation was still very cautious in the beginning of PM Lipponen's government term in spring 1995. But it soon became obvious that the purpose was to enhance the operation of the national innovation system to the benefit of the economy, the business environment and job creation. An appropriation increment of FIM 1.5 billion (i.e. > EUR 250 million, see also Table 1) was introduced on a permanent basis. Both the implementation and impact of this programme was considered as a success (Prihti et al. 2000).

In 2006, the RIC made important recommendations concerning the SHOKs and industryacademia collaboration, and was having an impact on the financial instruments of the Academy of Finland and Tekes (see STPC 2006). Building on previous experience with collaborations, 2007 marked the launch of a PPP policy model and instrument that further drove $R \& D$ intensity towards its peak in 2009.

The OSKE programme has been successful. OSKE funding had a major catalytic effect on R\&D in Finland's regions. The main beneficiaries of the OSKE were the small and medium-sized enterprises that were able to develop their R\&D within large urban areas (Prihti et al. 2000; Wallin \& Laxell 2013; OSKE 2014).

The Council's leadership role across electoral periods can be considered as one of the essential success factors of the innovation system (see e.g. OECD 2017). The role of the Council was instrumental in offering a platform for political dialogue and for having indepth discussions on how STI policies and R\&D targets should be implemented. In Finland the RIC had been essential in driving R\&D intensity in a well-balanced manner to serve the common interest, but its importance had started to weaken for various external and also internal reasons by 2012 (see Pelkonen et al. 2014).

While not all of these success factors have been in place in Finland, the authors conclude that the following eight factors are the most relevant in driving the success in raising $R \& D$ intensity:

- Raising the level of commitment of all stakeholders;

- Adoption and implementation of a multilaterally drafted STI policy vision; 
- Better multilateral understanding of the goals and strategy by participants that opens up a possibility to work based on shared views and a joint R\&D agenda;

- Possibility to enhance (long-term) partnerships between public and private players;

- Pooling of financial resources from various sources into more extended entities.

- Bringing together expertise from various stakeholders and fields of knowledge.

- Implementing measures by multiple stakeholders together often functions better and has more impact.

- Expressing long-term support and commitment of political decision-makers and top-level civil servants is a precondition for success, especially for significant renewals.

\subsection{Governance and implementation failures}

The implementation of policies to drive R\&D intensity is challenging, and therefore it is not surprising that some policy instruments did not reach their intended objectives. Moreover, as the Great Recession picked up speed Finnish GDP plummeted (and R\&D intensity peaked) in 2009, the economic and policy environment became more volatile and turbulent.

An overall failure in driving $R \& D$ intensity in Finland has been the introduction of tax incentives. Both during the 1980s and in 2013-2014 there were attempts to launch these policies. In the 2013-2014 period the R\&D tax credit did not succeed because of structural flaws, challenges in implementation, and a lack of uptake (Kuusi et al. 2016). Currently tax incentives for R\&D are again on the policy agenda and appeared as a recommendation on the new RDI roadmap of the Finnish government ${ }^{16}$ (RDI Roadmap 2020; Ali-Yrkkö et al. 2021).

As was pointed out by many of the interviewees, despite being based on a good idea - the diversification of the Finnish Economy and fostering collaboration between industry and academics - the implementation of the SHOKs did not work because the initial SHOK model did not take into account the specificities of each industry. The programme's evaluation identified some weaknesses in the SHOK model and suggested improvements (Lähteenmäki-Smith et al. 2013).

Surprisingly, the government program of 2015 decided to abruptly terminate the SHOK financing programme, leaving a vacuum in collaboration between industry and universities. These cuts in Tekes funding addressing all the cooperation programs between industry and academics have been a fundamental failure. A recent impact study (Piirainen et al. 2019) states that the SHOKs contributed greatly in the creation of lasting networks and culture of collaboration between research organisations and enterprises, and enabled platforms for negotiating strategic agendas and building consensus for example related to standards.

According to the interviewees, it is of foremost importance to pay attention to the specificities of sectors when designing and implementing STI policy instruments. Based

16 The RDI Roadmap (2020) states that the government will investigate the introduction of a tax incentive for R\&D activities. In its mid-term policy review (29/4/2021), the government decided to set up a parliamentary working group to explore ways to commit to the growth of public sector R\&D financing, which is required to achieve Finland's R\&D intensity target of $4 \%$ by 2030 . Decisions about possible incentive(s) will be made in the 2021 government budget session (Finnish Government 2021). 
on their experience there is an inherent risk that programs that work for one sector will fail when applied to other sectors. For example, several characteristics of the ICT sector are rather unique, and this has to be taken into account in policy making. Furthermore, some of the interviewees pointed out that in some cases public support may have crowded out private support. Unintended misallocation of support should be prevented as there is evidence it is likely to persist (see Busom et al. 2017).

Some of the interviewees mentioned that the more recent move in 2018 to the new organization Business Finland - a merger of Tekes and Finpro - has not convinced all stakeholders in the innovation policy arena. Worries were linked to the outcomes of a merger between two large organisations, both having different objectives, working methods, legal status and culture. The first views on the merger were rather critical (Koskinen 2017). Furthermore, the merger has shifted the attention more away from innovation and towards internationalisation, replacing the long-term capacity building and shock absorber approach with a short-term approach focusing on export target-setting with very high expectations. For example, parliamentary debate (Eduskunta 2017) did highlight the importance of fortifying internationalisation and export activities, but not much attention was paid to R\&D and how Finns could create new technologies and innovations in the first place. One obviously needs first something saleable before entering to the market. Hence, the balance of the Business Finland agenda has been somewhat unclear (see Alkio 2019). Since no external and public evaluation on Business Finland has yet been carried out, it is early to say anything definitive about the pros and cons of the merger.

The distinction between regional policy and STI policy has not always been successful. The tension between national STI policy and regional policy and more recently the policies of the biggest cities have undermined the systemic approach taken earlier when the belief was that the system is as good as its weakest link (see also Armstrong and Taylor 2000, Cai et al. 2018, OECD 2019). Giving multiple examples, they highlight that tackling interregional disparities can be seen as a way to reduce unwanted inequalities between individual regions while simultaneously promoting national economic growth.

The current vulnerability of the Finnish STI policy results from a situation where Ministries set their own national strategies that are not well enough integrated with the practices of different economic sectors and policy domains. This can lead to a situation where the average national policy impact on firms remains too low. Sectors and companies innovate in different ways and policy makers should take this better into account when designing and implementing policies. This weakness originates from the fact that there is too little coordination and governance for a systemic and integrated policy to emerge. As recently as the 2000s, the Sectoral Research Advisory Board (2007-2012) made efforts to coordinate activities between different stakeholders, including companies, but found it demanding especially without a mandate to make major decisions over the Ministries and without a decent budget of its own.

In addition, the lack of continuity and connections between government programmes is a major challenge. Finland used to be the world leader in innovation policy coordination, with Ministries and funding organisations cooperating more intensively in the late 1990s and 2000s in the context of cooperative cluster programmes initiated by RIC and jointly steered by ministries and funding organisations (see Pentikäinen 2000; Jääskeläinen 2001; Lemola 2001, 2002; Lemola et al. 2009) and where the RIC had high impact (see Finnish Government 2005; STPC 2006; RIC 2010). At the same time, the links of STI policy to other policy domains such as economic, regional, social and environmental policies were getting closer (e.g. STPC 2000, 2006).

Coordination deteriorated in many respects between 2012 and 2016, pushing the Finnish innovation system into a crisis. This period was characterised by weak economic growth, 
a continuous decrease of public and private $R \& D$ funding, diminishing industry-academia cooperation, weakening links between central government and regional efforts in RDI, and the dismantling of the original RIC (the last meeting was held in December 2014) and its ability organise multilateral discussions and decision-making advice. Diminishing public and private $R \& D$ resources and weakening governance led to a situation where Finland's relative innovation performance was weakening. For investments in $R \& D$ to happen, there was definitely a need for a stable policy environment in terms of regulation and instruments.

Moreover, since 2011/2012 the new generation of policymakers has put less emphasis on $\mathrm{RDI}$ and its role in economic and social policies, and has possibly had different ideas about the role and content of STI policy and leadership. This has led to a weakening of institutional memory (or social capital) with respect to the innovation system and its performance, and of cooperation procedures overall. The shrinking economy and rapidly growing government budget deficit increased pressures to make radical changes even in issues and entities that were not broken and were actually working relatively well.

For many policy domains to be designed and implemented successfully, new efforts in building effective cooperation are needed between the Ministries and in particular between the Ministry of Education and Culture and the Ministry of Economic Affairs and Employment. It becomes increasingly challenging to coordinate the design and implementation of policies without a series of governance reforms. Moreover, due to this increasing fragmentation of the innovation system and its operations, the scale of the measures is often too small to have lasting impact. ${ }^{17}$

The RIC, which used to play a coordination role bringing all the players from the innovation system together, no longer has this role (see discussion in section 4.2 on the reforms). No other bodies - such as Prime Minister's Office - have implemented compensatory coordination throughout the system. A bigger challenge however may be the absence of a clear long-term vision and a strong belief in risk taking in STI in the political and economic environment. It could also be very probable that due to changes in politics and the operating environment, working methods within ministries as well as RDI work and its position in business enterprises in the 2010s, the original RIC would not be an efficient response to today's challenges of governance, policy coordination and multilateral horizontal development actions. As some of the interviewees reflected, a new approach and operations model would in all likelihood be necessary.

\subsection{The role of policy and other factors}

Policy and other contextual factors are interlinked (see Figure 5) and the focus should be mainly on systemic policymaking. Long-term-oriented innovation policy certainly has played an important role in that it made possible a diverse set of capabilities that enabled industries to make the right decisions and grow (see e.g. PMO 2005; STPC 2006; Veugelers et al. 2009a, 2009b). From the 1980s until 2011 a balanced policy was developed to fund academic $R \& D$ and to encourage private $R \& D$. Initially, $R \& D$ intensity was driven by increased public sector R\&D only. However, policy guidelines are only one of the factors that influenced the RDI system and RDI investments.

$R \& D$ cutbacks were the result of the prolonged recession that Finland faced from the early 2012 until mid-2015, and the internationally relatively weak cost competitiveness of the

\footnotetext{
${ }^{17}$ Fragmentation of the innovation system means that human and economic resources are scattered across the country in relatively small units with inefficient scale and underperformance (see Kotiranta \& Rouvinen 2016; Veugelers et al. 2009a, 2009b).
} 
export sector (e.g. Kajanoja 2015). The Finnish GDP reached its 2008 level (in real terms) only in 2017. This period is called "the lost decade" (OECD 2017). At the same time productivity and competitiveness of the Finnish industry weakened compared to its foreign peers. Furthermore, the rapidly growing public foreign debt (from EUR 54 billion in 2008 to EUR 100 billion in 2015) and significant budget deficits resulted in diminishing resources that could be allocated to $\mathrm{R} \& \mathrm{D}$.

After 2011, Governments lost their faith in the regenerative force of R\&D on the economy and productivity and started to reduce public R\&D financing (see Laasonen et al. 2020; Figure 5). Driven by budget deficits public R\&D funding dropped for five consecutive years. This principle policy stance did send a negative signal for the business sector with respect to intangible investments and undermined trust between the players of the innovation system.

A key contextual driver has always been the small size of the Finnish domestic market that forced Finland to focus on knowledge accumulation and export markets. For a small economy, having a sustainable knowledge base has been a key issue. How talent can be attracted and retained in the future will certainly be of major importance.

Over time there have been considerable economic and societal changes affecting both the public sector and the private sector in Finland. Severe economic downturns, both the national recession of the early 1990 and the Great Recession from 2008 onward, have sped up structural changes in Finnish industries. In between these two major recessions, Nokia played a key role in driving R\&D intensity via large-scale RDI activities until reaching its peak market share in 2008. This triggered a behavioural change among policymakers and the focus shifted to stimulating private $R \& D$ via industry-academia collaborations. Nokia's successful role also explains why the private share of R\&D intensity used to be well over $70 \%$ instead of the current two thirds, and why the R\&D intensity peaked to $3.73 \%$ in 2009 . The downfall of Nokia's mobile phone business and simultaneous setbacks to the traditional backbone of the Finnish economy, the forest industry, in combination with the Great Recession distracted politicians and policy makers in their decision-making; faith in innovation policy and R\&D intensity started to diminish.

However, still in 2009-2011 policy-makers took counter-cyclical actions and increased $\mathrm{R} \& \mathrm{D}$, as can be seen in the Figure 5. A downward trend, and the government's pro-cyclical policy actions, started after that in 2012. In addition, roughly at the same time, Nokia's difficulties in relation to R\&D and product development (Savitz 2011) together with quickly diminishing market shares and negative operating margin of mobile phones led to a situation where the mobile business was eventually sold to Microsoft in the autumn 2013 (see e.g. Laamanen et al. 2015; Peltonen 2018). Some two years later, Microsoft had written off the deal and laid off thousands of employees during the process. In the heyday of Nokia in 2000, the company employed almost 25,000 workers in Finland; by 2013 only 4,700 were left. Today Nokia employs about 6,000 persons. On the positive side, the downfall of Nokia enabled the release of lots of talent into other industry fields and fuelled the Finnish start-up boom (Pajarinen \& Rouvinen 2013). Several hundreds of companies that are still active have been established by skilled ex-Nokia professionals in the 2010 s (e.g. Sucher $\&$ Winterberg 2015; Rönnqvist et al. 2015). 
Figure 5. Development of key indicators over the different development stages of Finnish STI policy in 2005-2020

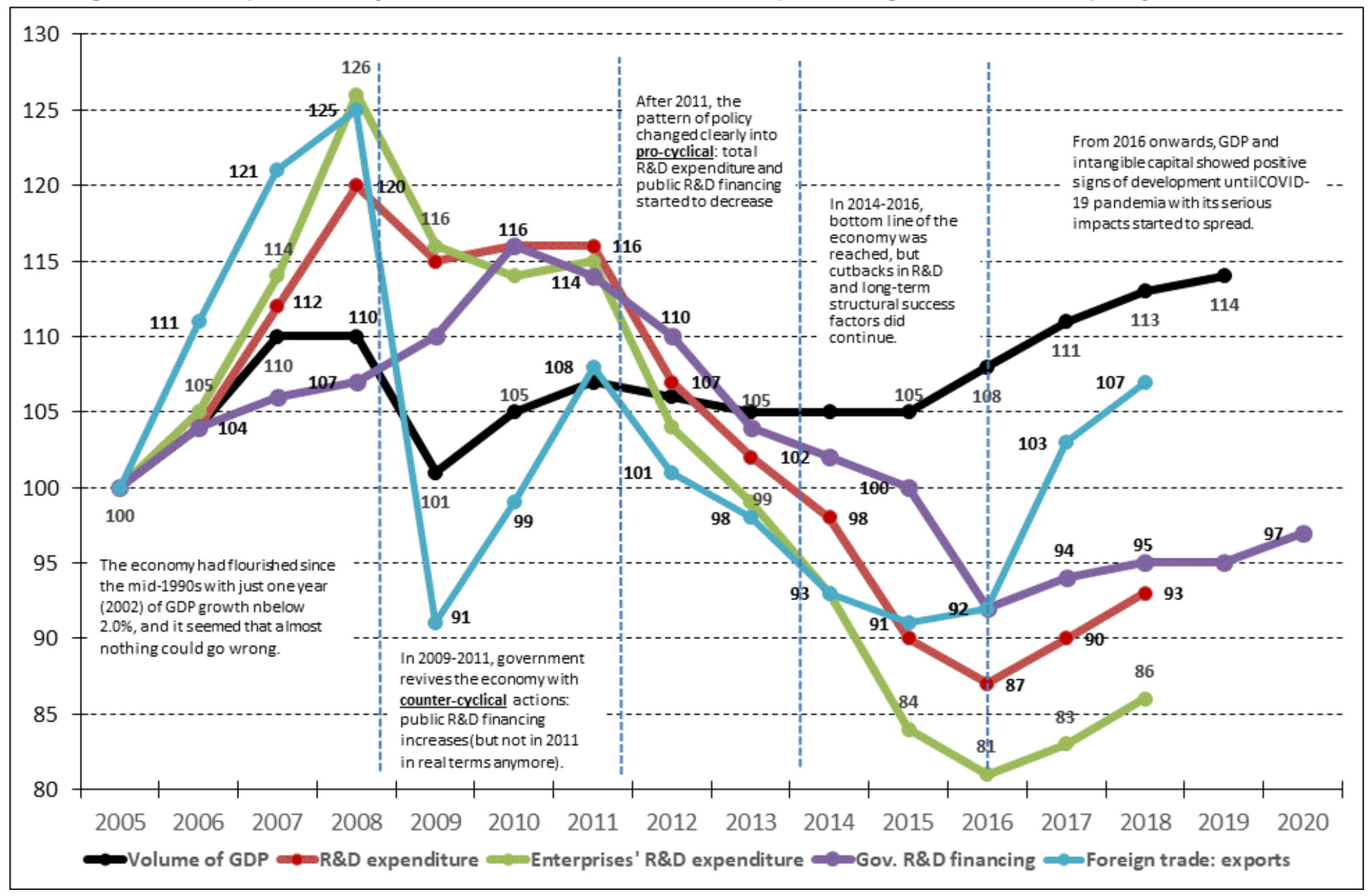

Note: Figure is based on Statistics Finland data on volumes of GDP and export, gross domestic expenditure on R\&D and Government R\&D financing in Finland from 2005 to 2020 (before COVID-19 crisis) in real terms (index $2005=100$, in 2010 prices). 
In terms of driving $R \& D$ intensity, the current landscape and technological cycle is different from that of the 1990s as the magnitude of the growth opportunities offered by emerging ICT technologies in the 1990s and the probability of success was in relative terms greater than the opportunity offered in the current competitive landscape. Along with this advancement and the narrowing window of options in relative terms, not surprisingly, both large enterprises and SME's have become more cautious and reluctant to focus on the development of radical innovations. Instead of raising their R\&D investments, they have been focusing more on incremental innovations (Ormala et al. 2014; Koski et al. 2019). 


\section{Conclusions and policy lessons}

For countries to be able to increase $R \& D$ intensity in a meaningful way, the big picture (including the current state of affairs in the economy and the innovation system, a longterm vision and a strategy for reaching the policy targets) should be clear to all the stakeholders. R\&D is only one important part of the big picture. What is decisive is the stage and direction of development of the national innovation system and its components. A sustainable policy approach needs to be systemic and therefore it requires that education, science, technology and innovation policies are integrated and are all heading to the same course. However, more important than setting targets is a thorough understanding and argumentation as to why and how additional R\&D investments are being made. Here R\&D quality, efficiency and impacts matters as much as R\&D quantity. This requires thorough systemic planning, foreign expert ex-ante evaluations and absolute R\&D targets set in interaction with the relevant ministries responsible for STI and the Ministry of Finance.

Even if (national) innovation systems are by nature systemic, their functioning depends largely on individuals that can lead, motivate and inspire. That Finland became world famous (for a limited time) for its innovation system and innovation policy was a result of hard and long teamwork jointly driven by visionary leaders from industry, politics, ministries and the RIC, and generally speaking, by innovative people across the labour market. Thus, the significant role that insightful leaders, experts and other individuals played in the development of STI policy and their impact on the direction and trend of the innovation system is probably much greater that is thought in general or how the history of STI policy has been written out (cf. Box 2).

For reaching R\&D targets industry needs to be fully committed; this can partly be stimulated via supporting industry-university and other PPP-based cooperation. Currently there is a broadening gap between universities and industry - on the EU level and especially in Finland - as the autonomy of universities made them focus on becoming internationally competitive in science and put less emphasis and establish fewer incentives for industry cooperation, especially when most of the funds for collaboration were cut in the 2015 Government Program (GP 2015).

For setting-up large overarching programmes based on megatrends all types of business actors have to be invited to take part in drafting the programmes, in order to raise the level of commitment of the private sector. Ministries should facilitate discussions and not steer them as too much public sector influence may limit commitments of key players. RDI roadmap (2020) should channel resources over time and not through one government only; this will smooth R\&D expenditures and make them more predictable over time. Stability of the system is the key, though it does not rule out the capacity for the changes the system needs in order to renew itself, create new competitive advantages and react to shifts in the operational environment. From all these perspectives, the main conclusions of the OECD (2017) review of the Finnish innovation system are still valid and should guide decisionmaking ${ }^{18}$.

18 The 2017 OECD review of the Finnish innovation system presented the following five key recommendations for Finland to tackle its economic challenges. 1) Re-balance R\&D policy and increase R\&D financing (some positive developments have occurred, and financing has increased). 2) Enhance the exploitation of R\&D results (some developments in boosting innovation in the business sector, but no major system-level changes or solutions made yet). 3) Intensify cooperation, develop new models for PPP-based activities (development of a new PPP-model among key ministries and public funding organisations is now underway). 4) Internationalisation: attract foreign talents and capital, create globally renowned ecosystems and centres of excellence (attraction has improved in terms of the amount of Venture Capital; development of innovation ecosystems with 
We conclude the following eight central factors and dimensions to have an impact on the reaching R\&D intensity targets: political factors (e.g. whether government prioritises $R \& D$, interests of political parties); economic issues (growth of GDP, estimates for future growth); public finances (balance of public budgets, debt-equity ratio); human resources (quality of education, sufficiency of well-educated); governance issues (debate culture, PPP-based advisory and collaborative forums); social factors (social capital, institutional memory, importance of trailblazers, visionaries and political leadership); business enterprise sector dynamics (e.g. industrial structure, $R \& D$ intensity of the business enterprise sector); and regulatory framework, infrastructure and technical issues (laws and degrees, regulations, standardisation, public procurement, availability of joint facilities and platforms).

On the basis of the long-term experience with $R \& D$ target setting, the study distilled three key lessons that are of relevance to Finland's peers as well as to Finland's current and future policy makers as to be able to set R\&D intensity targets in a sustainable and impactful manner:

- A systemic and integrated policy approach needs impactful coordination and governance. The ability of any such effort to have impact depends on its authority and its mandate given by political actors. Finland used to be world leading in STI policy coordination and multilateral collaboration, e.g. industryacademia cooperation. The RIC offered a forum for discussion and consensusmaking and an independent soundboard beyond government terms. Simultaneously, multiple STI agencies and ministries were coordinating their actions. Furthermore, via sectoral committees, strong coordination existed between the sectors and national policies. All these coordination actions made the STI policy approach more sustainable.

- A balanced innovation system with efficient joint PPP mechanisms will do better in absorbing shocks. Balance should be present in terms of paying attention to all key stakeholders, from a research, development and innovation perspective, but also in terms of making sure that policies are balanced and predictable over time. This is why in the first place public support should focus on collaboration, on programs that are nation-wide and lasting across government terms, and on supporting novel openings that would not be carried out without further public support. Political buy-in to the importance of $R \& D$ is a precondition for trust building and for lifting private $R \& D$ investments. Creating PPP efforts do not require new organizations, but new innovation policy approaches, initiatives and governance models that go across the borders of sectors, fields of administration and organisations to make this a priority.

- A key strategy to be able to absorb shocks to the economy and society is to invest in consistent and long-term capacity building. Enhancement of the knowledge base and comparative advantages should happen based on a diversity of skills and focus on more and better cooperation between various stakeholders. However, a long-lasting focus means there will be a need for insightful leadership and more diplomacy pushing aside organisational agendas and shortterm wins for the common economic and societal good of the entire country.

new policy instruments has been active for the past three years). 5) Enhance governance and steering of the innovation system on a-whole-of-government basis; create a new vision (although the RIC got a fresh start under the current government, no major changes occurred yet with regard to overall STI governance; a new long-term comprehensive vision is still missing although a national RDI roadmap was adopted in 2020). 
Given the grand challenges we face, visionary STI policy leaders, bridgebuilders and intermediaries will continue to be in high demand.

\section{Box 2. Good policy practice and the importance of leadership and continuity}

STI policy is primarily considered as an area that benefits from long-term policy trajectories, visionary leadership and compatible policy measures across its subdomains of science, technological development and innovation. Both the PM Paavo Lipponen's governments and PM Matti Vanhanen's governments showed a longsighted commitment to STI though with a different kind of policy toolkit. At the time those governments had a belief in multilateral collaboration for the common good and saw it as a precondition for growth of the economy and the success of the innovation system.

Social capital, institutional memory, trust building, collaborative culture and interaction across the borders between players and different types of STI activities are all crucial for a strong system. They enable knowledge flows and spill-overs that benefit both the creation and diffusion of innovation. Therefore, it is important to monitor how knowledge flows over institutional borders, as well as over governments and parties.

A system is as good as its weakest link. From the point of view of effective STI policy, this means that all stages from basic and applied research to development and innovation activities have to be sufficiently financed and of high standard. Likewise, a systemic inclusive dialogue between various organisations across different policy domains is needed when planning long-term policy initiatives and guaranteeing their sustainability.

To facilitate such a dialogue, there is a need for a platform that offers an arena for consensus making and an independent soundboard over government terms. This is exactly the role the PM-led RIC used to fulfil. Such a platform - although being in an advisory role and without a budget and legal right of decision over public bodies helped to balance policy issues, made it easier to reach shared views on policy designs between various players within the innovation system, and smoothed the path between basic research, applied research, development and various forms of innovation.

A balance between policy instruments that foster both research and innovation and that enhance industry-academia interaction was mainly absent in the 2010s to the detriment of the innovation system. That is why public support should, in the first place, focus on collaboration and on programs that are nation-wide and long-term as well as extending across the borders of policy domains and fields of administration. However, this can only happen if there is sufficient capacity and if there is the will across the innovation system to build joint views about the needs, objectives and measures of STI policy. 
34 | TARGETING R\&D INTENSITY IN FINNISH INNOVATION POLICY

Annex A. The evolution of Finland's R\&D expenditures by selected sector

Table 2. The evolution of Finland's R\&D expenditures by selected sector (in Million EURO and as shares of total)

\begin{tabular}{|c|c|c|c|c|c|c|c|c|c|c|c|c|c|c|c|c|}
\hline & 1995 & 2000 & 2005 & 2006 & 2007 & 2008 & 2009 & 2010 & 2011 & 2012 & 2013 & 2014 & 2015 & 2016 & 2017 & 2018 \\
\hline \multirow[t]{2}{*}{ I. Business enterprises } & 1373 & 3136 & 3877 & 4108 & 4513 & 5102 & 4847 & 4854 & 5048 & 4695 & 4602 & 4410 & 4047 & 3902 & 4028 & 4227 \\
\hline & $63 \%$ & $71 \%$ & $71 \%$ & $71 \%$ & $72 \%$ & $74 \%$ & $71 \%$ & $70 \%$ & $70 \%$ & $69 \%$ & $69 \%$ & $68 \%$ & $67 \%$ & $66 \%$ & $65 \%$ & $66 \%$ \\
\hline \multirow[t]{2}{*}{ Manufacturing sector } & 1128 & 2539 & 3113 & 3279 & 3611 & 4065 & 3880 & 3867 & 3878 & 3387 & 3283 & 3126 & 2716 & 2507 & 2520 & 2595 \\
\hline & $52 \%$ & $57 \%$ & $57 \%$ & $57 \%$ & $58 \%$ & $59 \%$ & $57 \%$ & $55 \%$ & $54 \%$ & $50 \%$ & $49 \%$ & $48 \%$ & $45 \%$ & $42 \%$ & $41 \%$ & $40 \%$ \\
\hline \multirow[t]{2}{*}{ ICT sector } & 585 & 1725 & 2224 & 2320 & 2554 & 2936 & 2847 & 2817 & 2770 & 2195 & 2081 & 2042 & 1602 & 1384 & 1339 & 1319 \\
\hline & $27 \%$ & $39 \%$ & $41 \%$ & $40 \%$ & $41 \%$ & $43 \%$ & $42 \%$ & $40 \%$ & $39 \%$ & $32 \%$ & $31 \%$ & $31 \%$ & $26 \%$ & $23 \%$ & $22 \%$ & $20 \%$ \\
\hline \multirow[t]{2}{*}{ II. Public sector, incl. non-profit } & 374 & 497 & 555 & 574 & 565 & 589 & 657 & 692 & 684 & 662 & 644 & 613 & 543 & 535 & 578 & 587 \\
\hline & $17 \%$ & $11 \%$ & $10 \%$ & $10 \%$ & $9 \%$ & $9 \%$ & $10 \%$ & $10 \%$ & $10 \%$ & $10 \%$ & $10 \%$ & $9 \%$ & $9 \%$ & $9 \%$ & $9 \%$ & $9 \%$ \\
\hline \multirow[t]{2}{*}{ III. Higher education sector } & 425 & 789 & 1042 & 1079 & 1165 & 1181 & 1283 & 1425 & 1432 & 1475 & 1438 & 1490 & 1481 & 1490 & 1567 & 1624 \\
\hline & $20 \%$ & $18 \%$ & $19 \%$ & $19 \%$ & $19 \%$ & $17 \%$ & $19 \%$ & $20 \%$ & $20 \%$ & $22 \%$ & $22 \%$ & $23 \%$ & $24 \%$ & $25 \%$ & $25 \%$ & $25 \%$ \\
\hline TOTAL R\&D expenditures & 2172 & 4423 & 5474 & 5761 & 6243 & 6871 & 6787 & 6971 & 7164 & 6832 & 6684 & 6512 & 6071 & 5926 & 6173 & 6438 \\
\hline R\&D intensity & $2.20 \%$ & $3.24 \%$ & $3.32 \%$ & $3.33 \%$ & $3.34 \%$ & $3.54 \%$ & $3.73 \%$ & $3.71 \%$ & $3.62 \%$ & $3.40 \%$ & $3.27 \%$ & $3.15 \%$ & $2.87 \%$ & $2.72 \%$ & $2.73 \%$ & $2.76 \%$ \\
\hline
\end{tabular}

Source: Statistics Finland; Note: Maximum (minimum) shares over tabulated time period highlighted in red (blue). 


\section{Annex B. Regional disparities in R\&D in Finland}

Regionally unbalanced economic and social development is an essential feature of the processes of technological change, innovation, and the accumulation of human and financial capital. R\&D and innovation play a significant role in these processes, such as through impactful spin-off and leverage effects on the regional economy (e.g. Dicken 1992; Saublens et al. 2007; EC 2020a). Consequently, R\&D and innovation-oriented regional policy typically aims at generating new businesses and knowledge which fortify societies' resilience to economic, social and technological challenges. However, there is a limit to the extent to which policy measures can prevent unequal development; it also needs to be emphasised that increasing levels of inequality can reduce the overall efficiency of the economy and society.

Regions differ significantly from each other in terms of competitiveness, their industries' capacity for renewal, social and financial capital, intellectual capacity and the efficiency of their operational environments. Differences are similarly apparent in knowledge externalities linked to geographic concentration. These include: a) technology spill-overs; b) interrelationships between various organisations, experts and fields of knowledge; c) proximity-based trust; d) common RDI infrastructures; e) availability of expertise in fields of strength in a given concentration and; f) rates of internal mobility.

Digitalisation of the economy and society has brought new dynamics into research and innovation (Guellec and Paunov 2018). Digital transformation will continue to cut down geographic distances as a barrier for multi-locational RDI collaboration and diffusion of knowledge. However, there is limited evidence on the effects of digitalisation on the spatial concentration of $\mathrm{R} \& \mathrm{D}$, innovation, and multilateral collaboration. As is indicated in recent OECD studies (Guellec and Paunov 2018; Paunov et al. 2019), there are no one-way conclusions about the impact of digitalisation on the geographic concentration of innovation. For instance, there is evidence of a diminishing effect of distance for knowledge spill-overs, as well as evidence indicating that the most dynamic cities can benefit more than others from digital technology when they are innovating.

As far as regional disparities in Finland are concerned, R\&D is most notably concentrated in four principal urban regions and the previously Nokia-driven region of Salo. The Capital region (covering Helsinki, Espoo and Vantaa), in addition to Tampere, Turku and Oulu, are the regions having the most resources to establish large and multidisciplinary centres that could become global poles of excellence and innovation. The regions mentioned in Table 3 below also differ from others in terms of human and financial resources. All these regions and cities possess in varying extents key qualities such as open and collaborative RDI environments, dynamic labour markets, high-quality business services and a critical mass of expertise in their fields of strengths.

Table 3 shows that the changes in the $R \& D$ shares of the main regions have been comparatively small since the 1990s. In general terms, the regional division of R\&D expenditures shows a rather stable and positive development from 1997 to the early 2010s, when the Finnish economy sank into recession. Especially Salo, Oulu and Tampere regions recorded relatively high annual growth figures in 1997-2011. Then, the economic and STI 
related challenges that Finland faced in the 2010s can be clearly seen in the growth figures for 2011-2018.

The Capital region, the biggest region in Finland with almost 1.2 million inhabitants in 2019 (over 1/5 of the total population), has managed to strengthen its position (in relative terms) as the centre of Finnish ecosystem development in the 2010s. Currently, there are globally well-known knowledge centres and innovation ecosystems such as those built around the Aalto University and VTT (in Otaniemi, Espoo) and the University of Helsinki. In 2018, the R\&D share of the Capital region climbed to almost $50 \%$.

\section{Table 3. The evolution of Finland's R\&D expenditures by main region.}

\begin{tabular}{|c|c|c|c|c|c|c|}
\hline & \multicolumn{6}{|c|}{ R\&D EXPENDITURES } \\
\hline & \multicolumn{4}{|c|}{ Amounts in million $€$} & \multicolumn{2}{|c|}{ Average annual growth rates } \\
\hline & 1997 & 2004 & 2011 & 2018 & $1997-2011$ & 2011-2018 \\
\hline \multicolumn{7}{|c|}{ CAPITAL REGION (Helsinki, Espoo, Vantaa) } \\
\hline Total R\&D expenditures region & 1321.9 & 2213.1 & 2997.9 & 3096,0 & $+6.0 \%$ & $+0.5 \%$ \\
\hline Total R\&D shares region & $45 \%$ & $42 \%$ & $42 \%$ & $48 \%$ & & \\
\hline Private R\&D expenditures region & 815.6 & 1482.2 & 2010.8 & 2058.6 & $+6.7 \%$ & $+0.3 \%$ \\
\hline Private R\&D shares region & $43 \%$ & $40 \%$ & $40 \%$ & $49 \%$ & & \\
\hline \multicolumn{7}{|l|}{ OULU REGION } \\
\hline Total R\&D expenditures region & 269.4 & 663,0 & 975.9 & 710.9 & $+9.6 \%$ & $-4.4 \%$ \\
\hline Total R\&D shares region & $9 \%$ & $13 \%$ & $14 \%$ & $11 \%$ & & \\
\hline Private $R \& D$ expenditures region & 186,0 & 528.7 & 790.5 & 529.5 & $+10.9 \%$ & $-5.5 \%$ \\
\hline Private R\&D shares region & $10 \%$ & $14 \%$ & $16 \%$ & $13 \%$ & & \\
\hline \multicolumn{7}{|l|}{ TAMPERE REGION } \\
\hline Total R\&D expenditures region & 354.9 & 793.8 & 1040.3 & 690.7 & $+8.0 \%$ & $-5,7 \%$ \\
\hline Total R\&D shares region & $12 \%$ & $15 \%$ & $15 \%$ & $11 \%$ & & \\
\hline Private $R \& D$ expenditures region & 248.8 & 622.5 & 844.9 & 475.2 & $+9,1 \%$ & $-7,9 \%$ \\
\hline Private R\&D shares region & $13 \%$ & $17 \%$ & $17 \%$ & $11 \%$ & & \\
\hline \multicolumn{7}{|l|}{ TURKU REGION } \\
\hline Total R\&D expenditures region & 179.2 & 315,0 & 366.4 & 427.2 & $+5,2 \%$ & $+2,2 \%$ \\
\hline Total R\&D shares region & $6 \%$ & $6 \%$ & $5 \%$ & $7 \%$ & & \\
\hline Private R\&D expenditures region & 84.4 & 171.8 & 182.9 & 219.3 & $+5,7 \%$ & $+2,6 \%$ \\
\hline Private R\&D shares region & $4 \%$ & $5 \%$ & $4 \%$ & $5 \%$ & & \\
\hline \multicolumn{7}{|l|}{ SALO REGION } \\
\hline Total R\&D expenditures region & 78.1 & 188.7 & 357.3 & 24,6 & $+11,5 \%$ & $-31,8 \%$ \\
\hline Total R\&D shares region & $3 \%$ & $4 \%$ & $5 \%$ & $0.4 \%$ & & \\
\hline Private R\&D expenditures region & 78.1 & 188,0 & 356,0 & 24,3 & $+11.4 \%$ & $-31.7 \%$ \\
\hline Private R\&D shares region & $4 \%$ & $5 \%$ & $7 \%$ & $0.6 \%$ & & \\
\hline PRIVATE R\&D FINLAND & 1916.7 & 3683.5 & 5047.5 & 4226.9 & $+7.2 \%$ & $-2.5 \%$ \\
\hline TOTAL R\&D FINLAND & 2904.9 & 5253.4 & 7163.8 & 6437.9 & $+6.7 \%$ & $-1.5 \%$ \\
\hline
\end{tabular}

Source: Statistics Finland. Note: Total (private) R\&D shares expressed as \% of total (private) R\&D Finland.

Almost all of the leading R\&D regions in Finland suffered during the 2010s. Only Turku (3rd largest with 332,000 inhabitants) recorded a clearly positive annual growth rate of 
R\&D (+2.2\%). The capital region was slightly above zero growth (+0.5\%). In Tampere (2nd largest, 411,000 inhabitants), a huge decline was experienced in the enterprise sector after 2011. The trends were quite similar in Oulu (4th largest, 253,000 inhabitants) in Northern Finland. The slower economic development of Turku compared to Tampere and Oulu in the 1990s and 2010s did relate to the structural change of the manufacturing sector: Turku was not so much dependent on the ICT sector. However, due to a versatile knowledge base and wider industrial foundations, Turku managed well to get over the economic difficulties and changes in the business environment.

From the point of view of regional disparities and changes in innovation dynamics, the exceptional case in Finland is Salo region (19th largest, 60,500 inhabitants). The rise and fall of Nokia can perhaps be seen better in Salo than anywhere else in the world. R\&D vanished quickly after Nokia's decision to close down the Salo factory in 2012 (the same year, Nokia made significant closedowns in Oulu too). In 2011, with an R\&D volume of EUR 356 million, the annual R\&D investment per inhabitant $(€ 5,500)$ of Salo was probably one of the highest in the world. The volume of R\&D expenditure had grown fivefold from the late 1990s to early 2010s, but declined rapidly thereafter. In 2018, less than seven percent was left of the R\&D that was undertaken in 2010. Before the collapse of ICT in Salo, the threat had become visible as early as the mid-2000s, when the first Finnish ICT companies and Nokia's subcontractors announced their decisions to relocate activities to the People's Republic of China and Estonia (e.g. Ali-Yrkkö 2010).

When looking at the R\&D shares of the regions in the public sector and the higher education institutions, the regional division of $\mathrm{R} \& \mathrm{D}$ is more skewed than that of the business enterprise sector. In 2018, the capital region accounted for $69 \%$ of all public sector R\&D. This is because most of the government's R\&D institutes are centred in the capital region. As far as the division of the higher education sector's R\&D is concerned, the four main regions used to account for almost $80 \%$ while the latest available share of $71 \%$ (in 2018) is clearly lower. This indicates the relatively strong increase of R\&D in the universities of Eastern Finland (in Kuopio and Joensuu), Jyväskylä, Lappeenranta, Vaasa and Lapland (Rovaniemi).

In order to improve the economic and social impact of research and innovation investments, regional and local level development measures and national policies should interact with and support one another. One of Finland's biggest challenges today is to create and maintain world-renowned clusters and ecosystems that can act as nodes that attract networked innovation actors, businesses and capital. Interaction aiming at significant synergy benefits in these centres could be improved by means of strategy processes and coordinated joint operating models, which Finland has more or less been missing after the SHOK and INKA instruments were discontinued around the mid-2010s (as is discussed in the main article).

Currently, major cities and public research organisations mainly make independent efforts to create various kinds of regional centres of expertise. Since state and cities have the best public resources for building attractive centres and innovation environments, the strategic use of intangible capital in cooperation with the state, the largest regions and the business enterprise sector would benefit the entire country. 


\section{References}

AF (Academy of Finland) (2014a). The state of scientific research in Finland 2014. The Academy of Finland, Helsinki.

AF (2014b). Finland's Strategy and Roadmap for Research Infrastructures 2014-2020. https://www.aka.fi/globalassets/2-suomen-akatemian-toiminta/4julkaisut/webroadmap2014eng.pdf? t $\mathrm{id}=0$ 0 0szSg0ut6HZKSE3qI6A\%3D\%3D\& t uuid=KXU9ajPzQU6G6JJwq_yJA\&_t_q=roadmap\&_t tags=language $\% 3 A$ en $\% 2 C$ Csiteid $\% 3 A 89 \mathrm{e} 2 \mathrm{ba} 17-5 \mathrm{f} 81-4 \mathrm{e} 18$ a6e227ce1774d3e5\%2Candquerymatch\& t hit.id=AkaFi Web Models Media PdfFile/26807aeb59d9-45d6-991e-c28219d77720\& t hit.pos $=3$

AF (2020a). Funding of the Academy of Finland. https://www.aka.fi/en/funding/

AF (2020b). Strategy for national research infrastructures in Finland 2020-2030: Creativity, renewal and knowledge on a sustainable basis. The Academy of Finland, Helsinki.

Akava (2017). Innovaatioista vauhtia yritysten kasvuun ja vientiin. Akavan teemaohjelma, hyväksytty Akavan hallituksessa 21.8.2017. Akava, Helsinki.

Ali-Yrkkö, J. \& R. Hermans (2002). Nokia in the Finnish Innovation System. Discussion Papers, No 811, ETLA - The Research Institute of the Finnish Economy, Helsinki.

Ali-Yrkkö, J. (2010; ed.). Nokia and Finland in a Sea of Change. ETLA B Series 244.

Ali-Yrkkö, J, M. Kalm, M. Pajarinen, P. Rouvinen, T. Seppälä, A. Tahvanainen (2013). Microsoft Acquires Nokia: Implications for the Two Companies and Finland. ETLA Brief 16.

Ali-Yrkkö, J., M. Deschryvere, K. Halme, A.-M. Järvelin,, J. Lehenkari, M. Pajarinen, K. Piirainen, A. Suominen (2021, forthcoming). Yritysten t\&k-toiminta ja t\&k-investointien kasvattamisen edellytykset. Prime Minister's Office Publications 2021, Finland.

Alkio, J. (2019). This is how Tekes and Finpro were railroaded into Business Finland - a peculiar combination of a public agency and limited company. Tekniikka \& Talous 22.3.2019.

Armstrong, H. W. \& J. Taylor (2000). Regional Economics and Policy. Blackwell, Oxford.

Becker, A., H. Hottenrott, A. Muklerjee (2020). Division of Labor in R\&D? Firm Size and Specialization in Corporate Research. Munich Papers in Political Economy, No. 3/2020. TUM School of Governance, Technical University of Munich.

$\mathrm{BF}=$ Business Finland (2020). Services of Business Finland. https://www.businessfinland.fi/en/for-finnish-customers/home/

Borowiecki, M. \& C. Paunov (2018). How is research policy across the OECD organised? Insights from a new policy database. OECD Science, Technology and Industry Policy Papers No. 55.

Busom, I., B. Corchuelo \& E. Martínez-Ros (2017). Participation inertia in R\&D tax incentive and subsidy programs. Small Business Economics 48 (1), 153-177. 
Cai, Y, R. Normann, R. Pinheiro \& M. Sotarauta (2018). Economic specialization and diversification at the country and regional level: introducing a conceptual framework to study innovation policy logics, European Planning Studies, 26:12, 2407-2426, DOI: $10.1080 / 09654313.2018 .1529142$

Committee Report (1980). Teknologiakomitean mietintö. Komiteanmietintö 1980:55.

Dahlman, C. J., J. Routti \& P. Ylä-Anttila (2006; eds.). Finland as a Knowledge Economy. Elements of Success and Lessons Learned. The World Bank, Washington, DC.

Dicken, P. (1992). Global shift. Paul Chapman, London.

EC $=$ European Commission (2017). Country Report Finland 2017: including an In-Depth Review on the prevention and correction of macroeconomic imbalances. Commission Staff Working Document. 22.2.2017, SWD(2017) 91 final.

EC (2018). Country Report Finland, 2018 European Semester: Assessment of progress on structural reforms, prevention and correction of macroeconomic imbalances, and results of in-depth reviews. 7.3.2018, $\operatorname{SWD(2018)~} 224$ final.

EC (2020a). Science, Research and Innovation Performance of the EU 2020: A fair, green and digital Europe. European Commission, Brussels.

EC (2020b). Regional Innovation 2019.

https://ec.europa.eu/growth/industry/policy/innovation/regional_en

Eduskunta (2017). Hallituksen esitys eduskunnalle laiksi Innovaatiorahoituskeskus Business Finlandista ja Business Finland -nimisestä osakeyhtiöstä. Eduskunnan pöytäkirja, asiakohta PTK $113 / 2017 \mathrm{vp}$

Finnish Government (2005). Government Resolution on the Structural Development of the Public Research System (only in Finnish). 7.4.2005. https://valtioneuvosto.fi/artikkeli/lasset publisher/statsradets-principbeslut-om-utveckling-av-det-offentligaforskningssystemet? 101_INSTANCE_LZ3RQQ4vvWXR_groupId $=1410845$

Finnish Government (2013). Government approved resolution on comprehensive reform of research institutes (in Finnish). Government Communications Department press release 5.9.2013. https://valtioneuvosto.fi/artikkeli/-/asset_publisher/principbeslutet-om-en-totalreform-avforskningsinstituten? 101_INSTANCE 3wyslLo1Z0ni_languageId=fi_FI

Finnish Government (2021). Government decides policy positions for remaining part of its term and for 2022-2025 General Government Fiscal Plan. Press release 274/2021, 29.4.2021. https://valtioneuvosto.fi/en/-//10616/government-decides-policy-positions-for-remaining-part-ofits-term-and-for-2022-2025-general-government-fiscal-plan

GP = Government Programme (2007). Programme of Prime Minister Matti Vanhanen's Government second Cabinet, 19 April 2007. A responsible, caring and rewarding Finland. Publications of the Prime Minister's Office.

GP (2011). Programme of Prime Minister Jyrki Katainen's Government, 22 June 2011. Publications of the Prime Minister's Office. 
GP (2015). Finland, a land of solutions. Strategic Programme of Prime Minister Juha Sipilä's Government, 29 May 2015. Government Publications 12/2015.

GP (2019a). Programme of Prime Minister Antti Rinne's Government, 6 June 2019. Inclusive and Competent Finland: socially, economically and ecologically sustainable society. Publications of the Finnish Government 2019:25.

GP (2019b). Programme of Prime Minister Sanna Marin's Government, 10 December 2019. Inclusive and Competent Finland: socially, economically and ecologically sustainable society. Publications of the Finnish Government 2019:33.

Guellec. D. \& C. Paunov (2018). Innovation policies in the digital age. OECD Science, Technology and Innovation Policy Papers, November 2018, No. 59, OECD Publishing, Paris, https://doi.org/10.1787/eadd1094-en

Haila K., T. Aarrevaara, M. Hjelt, H. Paavola, S. Palomäki, K. Pulkkinen, T. Raivio, H. Rannikko, S. Sepponen \& M. Valtakari (2018). Assessment of the research institutes and funding reform (TULA-reform). Publications of the Government's analysis, assessment and research activities $74 / 2018$.

Hjelt M., S. Sepponen, S. Roschier, A. Laine, M. Bröckl \& T. Raivio (2018). Impacts of the profiling funding on universities strategic planning and leadership. Evaluation report. Publications of the Ministry of Education and Culture, Finland 2018:27.

Hjelt, M., S. Roschier, T., S. Sepponen, D. Palmintera \& J. Mikkola (2019). The evaluation of VTT 2018. Publications of the Ministry of Economic Affairs and Employment, Ministry 2019:6.

Huenermund P., \& Czarnitzki, D. (2019). Estimating the causal effect of R\&D subsidies in a panEuropean program. Research Policy. https://doi.org/10.1016/j.respol.2018.08.001

Husso K. \& P. Raento (2002). Science policy and research in Finland. Fennia 180: 1-2.

Jääskeläinen J. (2001). Cluster - between science and policy. From industrial policy to social policy (in Finnish). The Research Institute of the Finnish Economy (ETLA), Series A 33.

Kajanoja, L. (2015). Paljonko kustannuskilpailukyvyn pitäisi parantua? Kansantaloudellinen aikakauskirja, 111(3).

KEINO (2020). Competence center for Sustainable and Innovative public procurement. https://www.hankintakeino.fi/en/about-keino

Kortesoja, A., M. Hjelt, T. Miller, S. Palomäki \& S. Sepponen (2017). Kaupunkien uusi rooli innovaatioiden edistämisessä: INKA-ohjelman loppuarviointi. Publications of the Ministry of Economic Affairs and Employment, Enterprises 40/2017.

Koski, O., K. Husso, P. Kutinlahti, M. Huuskonen \& S. Nissinen (2019). Outlook for Finland's innovation policy. Publications of the Ministry of Economic Affairs and Employment 2019:18.

Koskinen, A. L. (2017). Finpro and Tekes will be merged - Entrepreneurs got angry: 'I haven't met anyone who would support the proposal" (in Finnish). Aamulehti, 28.3.2017.

Kotiranta, A. \& P. Rouvinen (2016). OECD Reviews of Innovation Policy: ETLA Background Report. ETLA, Helsinki. 
Kuusi T., M. Pajarinen, P. Rouvinen \& T. Valkonen (2016). A Study on the Finnish R\&D Tax Credit of the Years 2013-2014. ETLA Reports 51 (in Finnish).

Laamanen, T., J.-A. Lamberg \& E. Vaara (2015). Explanation of success and failure in management learning: what can we learn from Nokia's rise and fall? Academy of Management Learning \& Education 15(1), 2-25.

Laasonen, V., J. Kolehmainen \& M. Sotarauta (2020). The complexity of contemporary innovation policy and its governance in Finland. Innovation: The European Journal of Social Science Research, https://doi.org/10.1080/13511610.2020.1842176.

Lemola, T. (2001). Science, technology and innovation for the best of a society (in Finnish). VTT Group for Technology Studies, Working papers 57.

Lemola T. (2002). Convergence of national science and technology policies: the case of Finland. Research Policy 31 (2002), 1481-1490.

Lemola T. (2020) Kohti uutta tutkimus- ja innovaatiopolitiikkaa - Suomen tiede-, teknologia- ja innovaatiopolitiikan kehityskaari 1960-luvulta 2020-luvulle. Vastapaino, Tampere.

Lemola, T., J. Hukkinen, M. Kuisma, K. Viljamaa \& H. Lahtinen (2010). Ympäristöklusterin tutkimusohjelman loppuarviointi. Ympäristöministeriön raportteja 8/2010.

Leppälahti, J. (2018). The rise and fall of the Research and Innovation Council in 1990-2018 (in Finnish). Uusi Suomi, blogs 27.8.2018.

Leskin, P. (2019). The 50 most high-tech cities in the world. Business Insider, 2.4.2019.

Lähteenmäki-Smith, K. (2014). Implementing Innovation Policy. In Halme, K., I. Lindy, K. A. Piirainen, V. Salminen \& J. White (eds.): Finland as a Knowledge Economy 2.0 - Lessons on Policies and Governance, 97-112. The World Bank, Washington, DC.

Lähteenmäki-Smith K., K. Halme, T. Lemola, K. Piirainen, K. Viljamaa, K. Haila, A. Kotiranta, M. Hjelt, T. Raivio, W. Polt, M. Dinges, M. Ploder, S. Meyer, T. Luukkonen \& L. Georghiou (2013). "Licence to SHOK?" External evaluation of the strategic centres for science, technology and innovation. Publications of the Ministry of Employment and the Economy, Innovation 1/2013.

ME = Ministry of Education (2008). Education and research 2007-2012 development plan. Ministry of Education.

ME (2009). National-level research infrastructures: Present state and roadmap: Summary and recommendations. Ministry of Education.

MEAE = Ministry for Economic Affairs and Employment (2018). Agenda for sustainable growth http://urn.fi/URN:ISBN:978-952-327-372-6

MEC = Ministry of Education and Culture (2012). Education and Research 2011-2016 a development plan. Reports of the Ministry of Education and Culture, Finland 2012:3.

MEC (2017a) Open science and research leads to surprising discoveries and creative insights: Open science and research roadmap 2014-2017. Publications of the Ministry of Education and Culture, Finland 2014:21. 
MEC (2017b). Vision for higher education and research in Finland 2030. Ministry of Education and Culture.

Mohnen P. (2019). Perspectives on R\&D as a policy target. OECD Working Party on Innovation and Technology Policy.

OECD (2017). OECD Reviews of Innovation Policy: Finland. OECD Publishing, Paris. https://read.oecd-ilibrary.org/science-and-technology/oecd-reviews-of-innovation-policy-finland2017 9789264276369-en\#page1

OECD (2019). Regions in Industrial Transition: Policies for People and Places, OECD Publishing, Paris, https://doi.org/10.1787/c76ec2a1-en.

OECD (2020). "Finland: Business Dynamics", OECD Insights on Productivity and Business Dynamics, December 2020, https://www.oecd.org/sti/ind/oecd-business-dynamics-insightsfinland.pdf

OECD (2021). R\&D intensity as a policy target: Lessons from 11 international case studies, OECD Working Party on Innovation and Technology Policy. Available at: https://community.oecd.org/docs/DOC-194222

Ormala, E., S. Tukiainen \& J. Mattila (2014). Industrial innovation in transition. Aalto-yliopiston julkaisusarja KAUPPA + TALOUS 5/2014.

Ormala, E. (2019). Suomen kilpailukyvyn ja talouskasvun turvaaminen 2020-luvulla: selvityshenkilön raportti. Työ- ja elinkeinoministeriön julkaisuja 1/2019.

OSKE $=$ Centre of Expertise Programme (2014). Osaamiskeskusohjelma, tuloksia ja käytäntöjä 2007-2013. http://www.e-julkaisu.fi/OSKE/\#pid=1

Owal Group (2016). Impact evaluation of the Universities Act reform. Publications of the Ministry of Education and Culture, Finland 2016:30

Pajarinen, M. \& P. Rouvinen (2013). Nokia's Labor Inflows and Outflows in Finland: Observations from 1989 to 2010. ETLA Reports 10.

Pajarinen, M., P. Rouvinen \& I. Ylhäinen (2017). Are competitiveness reports by IMD and WEF fit to support the conduct of economic policy in Finland? Publications of the Government's Analysis, Assessment and Research Activities 51/2017 (in Finnish with English abstracts).

Paunov, C., D. Guellec, N. El-Mallakh, S. Planes-Satorra \& L. Nüse (2019). "On the concentration of innovation in top cities in the digital age", OECD Science, Technology and Industry Policy Papers, No. 85, OECD Publishing, Paris, https://doi.org/10.1787/f184732a-en.

Pelkonen, A., M. Nieminen \& J. Lehenkari (2014). The evaluation of the operation and impact of the Research and Innovation Council. Publications of the Ministry of Education and Culture 2014:6.

Peltonen, T. (2018). Towards Wise Management: wisdom and Stupidity in Strategic Decisionmaking. Palgrave Macmillan, London.

Pentikäinen, T. (2000). Economic evaluation of the Finnish cluster programmes. VTT, Group for Technology Studies, Working paper 50. 
Piirainen, K. A. (ed.), K. Halme, A.-M. Järvelin, T. Fängström, H. Engblom, A. Mensink \& T. Åström (2019). The big three - Impact study of research organisations, large enterprises and SHOKs. Business Finland Report 4/2019.

PMO = Prime Minister's Office (2004a). Strengthening competence and openness - Finland in the Global Economy. Interim report. Prime Minister's Office, Helsinki.

PMO (2004b). Osaava, avautuva ja uudistuva Suomi. Suomi maailmantaloudessa -selvityksen loppuraportti. Valtioneuvoston kanslian julkaisusarja 19/2004.

PMO (2005). Government's Strategy Document 2005. Publications of the Prime Minister's Office 1/2005 (in Finnish)

PMO (2006b). Government's Strategy Document 2006. Publications of the Prime Minister's Office 3/2006 (in Finnish)

PMO (2006a). Impact assessment of the Government's Strategy Document 2005. Publications of the Prime Minister's Office 4/2006 (in Finnish)

Prihti, A., L. Georghiou, E. Helander, J. Juusela, F. Meyer-Krahmer, B. Roslin, T. SantamäkiVuori \& M. Gröhn (2000). Assessment of the additional appropriation for research. Sitra Reports Series, 2.

RDI Roadmap (2020). Solutions for a sustainable and developing society: Objectives and targets of the National Roadmap for Research, Development and Innovation: A new beginning for RDI cooperation between companies and research organisations. Valtioneuvosto, 23 April 2020. https://minedu.fi/documents/1410845/22508665/The+National+Roadmap+for+Research\%2C+D evelopment+and+Innovation/e9566011-2acc-35b2-7b45-

279387991430/The+National+Roadmap+for+Research\%2C+Development + and+Innovation.pdf

RIC $=$ Research and Innovation Council (2010). Research and Innovation Policy Guidelines for 2011-2015. The Research and Innovation Policy Council of Finland, Helsinki.

RIC (2014). Reformative Finland: Research and innovation policy review 2015-2020. The Research and Innovation Policy Council of Finland, Helsinki.

RIC (2017). Vision and road map of the Research and Innovation Council of Finland. https://valtioneuvosto.fi/documents/10184/4102579/Vision_and_roadmap_RIC.pdf/195ec1c2$\underline{\text { 6ff8-4027-9d16-d561dba33450 }}$

RIC (2020). Council's activities and meetings 2016-2019 (in Finnish). https://valtioneuvosto.fi/tin/kokoukset.

Rönnqvist, R., A. Hakonen \& M. Vartiainen (2015). The Bridge Program - participant perspectives. Aalto University publication series, Science + Technology 4/2015.

Saublens, C., G. Bonas, K. Husso, P. Komarek, K. Koschatzky, C. Oughton, T. Santos Pereira, B. Thomas \& M. Wathen (2007). Regional Research Intensive Clusters and Science Parks. European Commission, Brussels.

Savitz, E. (2011). CEO's "Burning Platform" Memo Highlights Nokia's Woes. Forbes, Feb 9, 2011. 
Sheehan J., \& Wyckoff A. (2003), Targeting R\&D: Economic and Policy Implications of Increasing R\&D Spending. OECD Science, Technology and Industry Working Papers 2003/8, OECD Publishing, Paris, https://dx.doi.org/10.1787/072772055603

Sitra (2005). Making Finland a leading country in innovation. Final report of the Competitive Innovation Environment Development Programme. Sitra, Helsinki.

SPC $=$ Science Policy Council of Finland (1973). The development lines of Finnish science policy in the 1970s (1973). Science Policy Council of Finland, Helsinki (in Finnish)

Startup Genome (2020). Rankings 2020: Top 100 Emerging Ecosystems. https://startupgenome.com/article/rankings-top-100-emerging

STPC $=$ Science and Technology Policy Council of Finland (1996). STPC Policy Review: Knowledge-based society. Science and Technology Policy Council of Finland, Helsinki.

STPC (2000). Review 2000: The challenges of knowledge and expertise. Science and Technology Policy Council of Finland, Helsinki.

STPC (2003). STPC Policy Review: Knowledge, innovation, internationalisation. Science and Technology Policy Council of Finland, Helsinki.

STPC (2006). STPC Policy Review: Science, technology, innovations. Science and Technology Policy Council of Finland, Helsinki.

Sucher, S. J. \& S. J. Winterberg (2015). Nokia's Bridge Program: Redesigning Layoffs. Harvard Business School Case 315-002, February 2015.

Valtakari, M., J. Nyman, K. Haila, M. Hjelt, S. Sepponen, A.-M. Järvelin \& K. Halme (2018). Evaluation of pre-commercialisation activities of Tekes - TUTL and Innovation Scout. Business Finland reports 2/2018.

Veugelers, R., K. Aiginger, D. Breznitz, C. Edquist, G. Murray, G. Ottaviano, A. Hyytinen, A. Kangasharju, M. Ketokivi, T. Luukkonen, M. Maliranta, M. Maula, P. Okko, P. Rouvinen, M. Sotarauta, Tanayama, T., O. Toivanen \& P. Ylä-Anttila (2009a). Evaluation of the Finnish National Innovation System - Policy report. Published by Taloustieto Ltd on behalf of the Ministry of Education and the Ministry of Employment and the Economy.

Veugelers, R., K. Aiginger, D. Breznitz, C. Edquist, G. Murray, G. Ottaviano, A. Hyytinen, A. Kangasharju, M. Ketokivi, T. Luukkonen, M. Maliranta, M. Maula, P. Okko, P. Rouvinen, M. Sotarauta, T. Tanayama, O. Toivanen \& P. Ylä-Anttila (2009b). Evaluation of the Finnish National Innovation System - Full report. Published by Taloustieto Ltd on behalf of the Ministry of Education and the Ministry of Employment and the Economy.

Wallin, J. \& P. Laxell (2013). Alueet globaaleissa ekosysteemeissä - Osaamiskeskusohjelman loppuraportti. Publications of the Ministry of Employment and the Economy, Innovation 19/2013.

Wennberg, M., N. Korhonen \& M. Koramo (2018). Korkeakoulu-uudistusten vaikutusten arviointi. Publications of the Ministry of Education and Culture 2018:3 